\title{
Construcciones de falsa cúpula en el Valle del Duero
}

\section{ORIGEN DE LAS CONSTRUCCIONES DE FALSA CÚPULA}

Las construcciones que pastores y campesinos han edificado en el campo sirven de refugio permanente o temporal a personas y animales. Estos pequeños edificios son un excelente ejemplo de adaptación arquitectónica al medio natural, en el que no desentonan ni por la escala ni por los materiales, de tal modo que llegan a formar parte del paisaje en el que son un elocuente testimonio de humanización.

La variedad de estas construcciones es muy grande; en un paseo por nuestros campos podemos fácilmente toparnos con cabañas, excavadas en desniveles del terreno o levantadas con material vegetal, con chozos de pastores, con palomares ', casetas de era, en las cercanías de los pueblos, pozos y otras formas muy variadas. Nuestro objeto de estudio, en esta ocasión, son aquellas que se cubren con falsa cúpula, también conocida como cúpula de aproximación de hiladas ${ }^{2}$; el sistema consiste en cerrar, por encima, un espacio circular o cuadrangular, en cuyo caso se ochava mediante trompas o pechinas, con hiladas de piedras o adobes, colocados paralelamente al suelo y ligeramente salientes con respecto a las hiladas inferiores. Esta técnica es de origen muy antiguo; aparece por primera vez en el Neolítico, en viviendas del Mediterráneo oriental o en las tumbas megalíticas de Europa, como a continuación veremos.

Algunos autores consideran que las casas de planta redonda son las más antiguas; se han descubierto en poblados neolíticos de Oriente Medio, como Jericó o Karim-Sahir, del VII milenio, con muros de piedra y adobe y techumbre vegetal ${ }^{3}$. Sin embargo, son más los lugares en que aparecen casas de la misma antigüedad pero de planta rectangular ${ }^{4}$.

1 Sobre los que disfrutamos de una excelente monografía: F. P. Roldán Morales, Palomares de barro de Tierra de Campos (Valladolid, 1983).

2 A. Blanco Freijeiro, Arte Griego (Madrid: CSIC, 1982), p. 32.

3 G. Nieto Gallo, Prebistoria (Madrid: UNED, 1981), pp. XXIV-5 y 6.

4 G. Nieto Gallo, op. cit., pp. XXIV-5 y 10. 
De este tipo son también las más abundantes en Europa en el Neolítico.

Parece ser que la falsa cúpula tiene su origen en la cubrición de espacios circulares o poligonales. La arqueología nos informa de que las primeras cubiertas de este tipo son las de las casas de algunos poblados de Oriente Medio, del V milenio, como Arpasiyya y Tell Halaf, aunque actualmente algunos arqueólogos discuten esta primacía; es posible que las de Europa sean, por lo menos, tan antiguas. Las casas de Arpasiyya tienen planta circular de gran diámetro, 8 a 10 metros, cubierta con falsa cúpula en forma de ojiva (fig. 1) y una especie de atrio rectangular delante ${ }^{5}$. Parecidas son las de Tell Halaf ${ }^{6}$. De la misma época son las viviendas de Kirokitia, en Chipre, de piedra y adobe, cuya falsa cúpula tiene un orificio en la parte superior central para la salida de humos ${ }^{7}$. Este tipo de bóvedas se utilizó posteriormente en monumentos funerarios de zonas montañosas de Oriente Medio y del Cáucaso. Más tardíos aún son los monumentos megalíticos del norte de Africa y del sur de la India ${ }^{8}$.

En el II milenio se levantan en Creta y en Grecia numerosas tumbas tipo «tholos»; entre todas destacan por su monumentalidad las de Micenas, especialmente el Tesoro de Atreo (fig. 1)?

En Europa occidental la técnica de la aproximación de hiladas aparece unida a un fenómeno cultural: el Megalitismo, que se manifiesta fundamentalmente en la construcción de grandes sepulturas colectivas por parte de sociedades neolíticas, desde fines del $\mathrm{V}$ milenio. A este rito de enterramiento colectivo, que también se hizo en cuevas naturales y artificiales o en túmulos de tierra, se unen otros rasgos como el culto a la diosa madre. Su difusión comprende la fachada atlántica de Europa y algunas zonas mediterráneas (fig. 2).

El origen de este fenómeno se ha localizado generalmente en el Mediterráneo oriental, de donde habrían venido pobladores que buscaban metales y difundían, a la vez, las ideas religiosas que fueron la causa o razón de las inhumaciones colectivas ${ }^{10}$. Actualmente esta teoría es rechazada por la mayoría de los arqueólogos. La razón principal es que

5 W. Muller y G. Vogel, Atlas de Arquitectura (Madrid: Alianza, 1984), I.

6 G. Nieto Gallo, op. cit., p. XXIV-10; M. Almagro, Manual Historia Universal. Prehistoria (Madrid, 1960), p. 510.

G. Nieto Gallo, op. cit., p. XXIV-12.

8 Ibid., p. XXIX-17.

9 A. Blanco Frejeiro, op. cit., pp. 31-33; M. Almagro, op. cit.

10 M. Almagro, op. cit., pp. 639-710. 

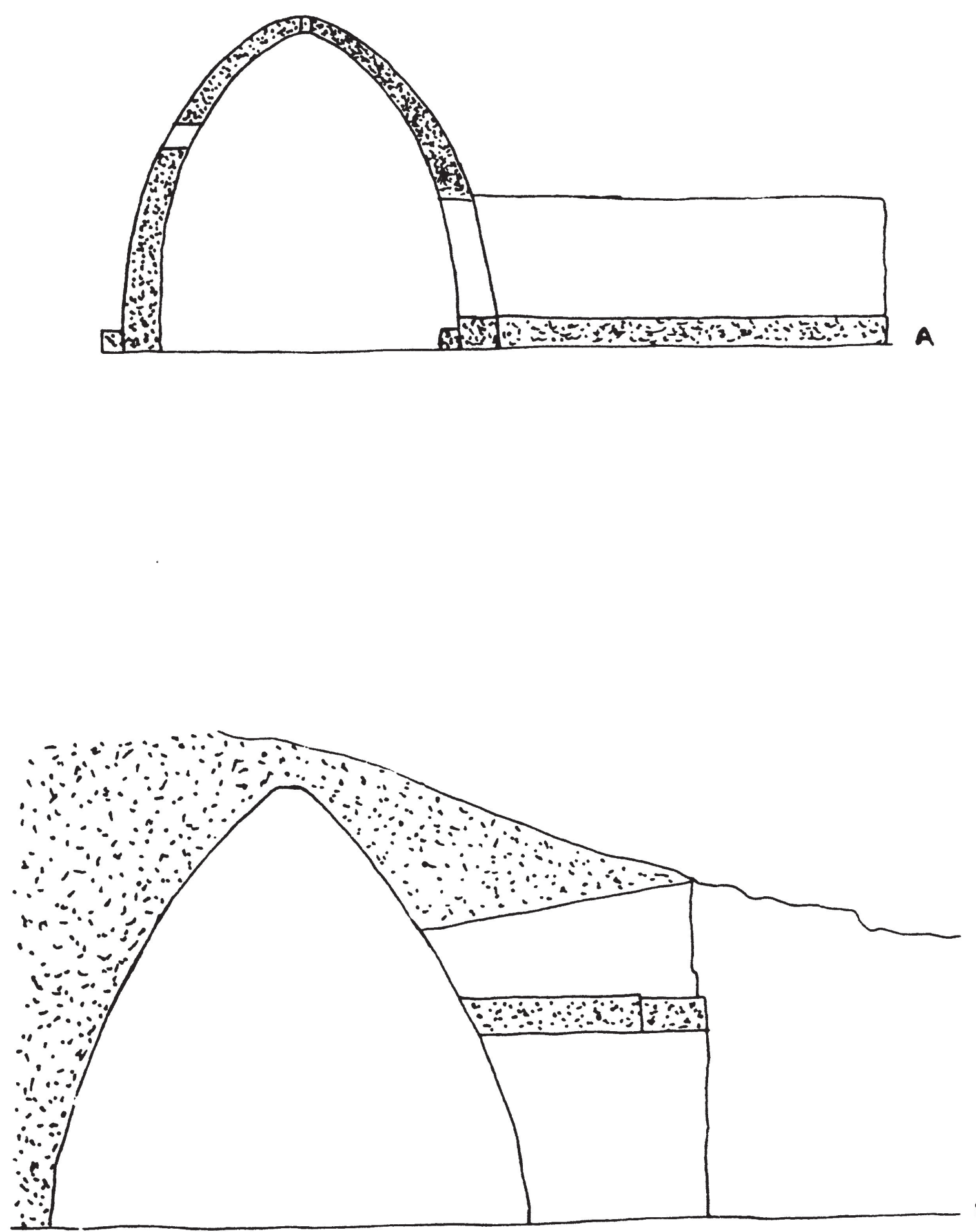

Fig. 1.-a) Casa de Arpasiyya. b) Tumba conocida con el nombre de Tesoro de Atreo, en Micenas. 


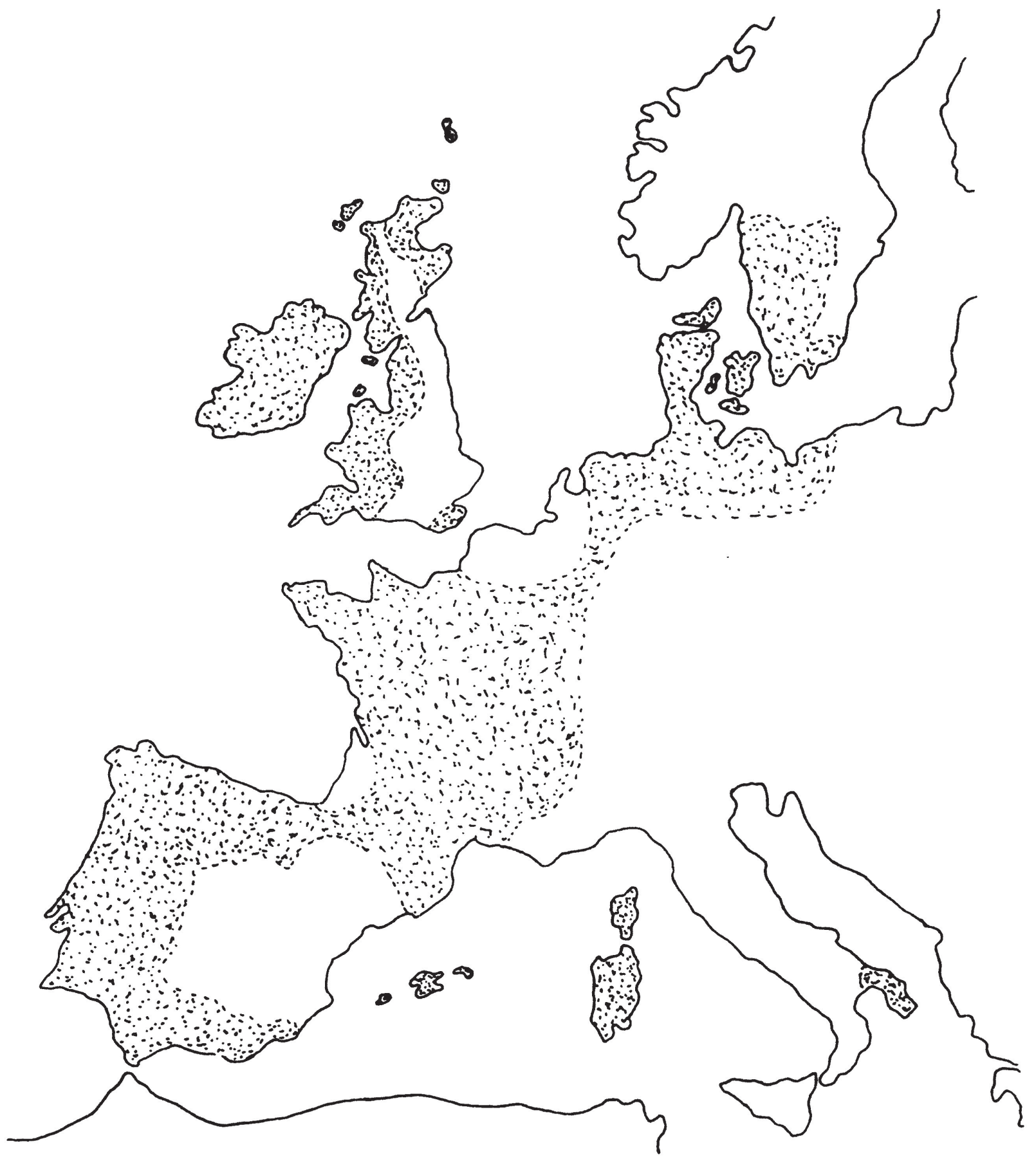

Fig. 2.-Difusión del fenómeno megalítico en Europa occidental. 
las fechas que se están obteniendo por el c-14 son más antiguas de lo que antes se creía, y el fenómeno megalítico está claramente ligado a culturas neolíticas, por lo que se cree que es anterior a las construcciones orientales ${ }^{11}$. De entre todos los focos megalíticos europeos hay dos, Bretaña y Portugal, que presentan fechas muy antiguas, de fines del V milenio, y son considerados probables lugares de origen del megalitismo europeo. Algunos estudiosos, como Renfrew, opinan que pudo surgir en diferentes regiones de forma independiente ${ }^{12}$.

Los sepulcros de corredor más antiguos de la Península Ibérica son los portugueses. Desde Portugal es probable que se extendieran a Andalucía, donde se conservan importantes ejemplos, como el dolmen de Matarrubilla (Sevilla), o la cueva del Romeral (Málaga). También desde Portugal se extendería a Extremadura y el valle del Duero, en el que existe una zona en las provincias de Salamanca y Zamora con gran cantidad de sepulcros de corredor, con cámaras circulares o poligonales construidas a finales del IV milenio y hasta mediados del III ${ }^{13}$. Otro foco importante es el burgalés, cuyos ejemplares se sitúan al norte del río Arlanza. Su tipología es parecida a la de los salmantinos y zamoranos; unos estuvieron cubiertos con madera y tierra, como demuestra el hoyo central para un poste del dolmen de Cubillejo de Lara ${ }^{14}$; otros con falsa cúpula, como el de Las Arnillas ${ }^{15}$. El sepulcro de Los Zumacales, en Simancas, serviría de unión entre ambos focos; el burgalés está en contacto con la zona alavesa y pirenaica.

Finalmente haremos mención de dos culturas que florecieron en sendas islas mediterráneas y que construyeron en época prehistórica grandes monumentos de carácter megalítico, en los que, a veces, se usaron las falsas cúpulas para su cubrición.

A mediados del II milenio apareció en las islas de Mallorca y Menorca una cultura del Bronce que levantó extensos poblados amurallados, con torres defensivas de planta cuadrada, muy pocos, o circular, la mayoría, conocidos como «talayotes». Su interior podía ser macizo o con una cámara central que se cubría con grandes losas apoyadas en el muro

11 C. RenfREw, El alba de la civilización (Madrid, 1986). Cf. especialmente cap. 7 , «El enigma de los megalitos», pp. 132-159; AA.VV., El megalitismo en la Península Ibérica (Madrid: Ministerio de Cultura, 1987).

12 Op. cit., pp. 157-159.

13 G. Delibes, «El Neolítico», en Historia de Castilla y León (Valladolid, 1985), I, pp. 29-30.

14 J. L. URibarRi ANgulo, El fenómeno megalítico burgalés (Burgos, 1975), p. 64.

15 G. Delibes y A. Esparza, "Neolítico y Edad del Bronce», en Historia de Burgos (Burgos, 1985), I, p. 127. 
y que iban cerrándose por el procedimiento de aproximación de hiladas; en algunos había una columna central en la que apoyaba la bóveda ${ }^{16}$.

En el mismo milenio comenzó en la isla de Cerdeña la cultura nuráguica, que existió hasta la conquista romana. Su rasgo más característico son unas construcciones defensivas, «nuragas», que también servían de lugares de culto. Son torres troncocónicas, de piedra de sillarejo, con cámara interior cubierta con falsa cúpula; con el paso del tiempo evolucionaron hacia formas más complejas de varias torres adosadas y cámaras superpuestas ${ }^{17}$.

Recapitulando, podrían resumirse una serie de características acerca del momento y las circunstancias de la aparición de las construcciones que nos ocupan:

- La técnica de la falsa cúpula o de aproximación de hiladas surgió de forma independiente, y casi contemporánea, en el Neolítico en Oriente Medio y en Europa occidental.

- En Europa se empleó en los sepulcros colectivos típicos del fenómeno megalítico, desde fines del V milenio hasta el III.

- Estos sepulcros eran de planta circular o poligonal, de muros construidos con grandes losas verticales o de sillarejo. La cubierta podía ser de madera y tierra, de grandes losas horizontales o de aproximación de hiladas.

- Hay variaciones técnicas que dependen de la naturaleza de los materiales autóctonos y de factores sociales.

- Los pueblos que construyeron estas tumbas colectivas eran ganaderos y agricultores. Sólo al final del Megalitismo aparece el metal de forma marginal.

\section{CONSTRUCCIONES DE FALSA CÚPUla EN EL VALLE DEL DUERO}

\section{Chozos pastoriles}

Son construcciones muy elementales que servían de vivienda ocasional a los pastores de los rebaños estantes. Forman parte de unos recintos para ganado ovino denominados generalmente corrales o tenadas, que se sitúan en pleno campo, normalmente en montes comunales o en cañadas, aunque eran de propiedad privada. Un corral es un espacio

16 L. Pericot, Las islas Baleares en los tiempos prebistóricos (Barcelona, 1975), especialmente pp. 55-102.

17 M. Almagro, op. cit., pp. 651-653. 
muy amplio, de forma rectangular, cercado por muros de piedra, de mampostería en seco o trabada con barro, una parte del corral estaba cubierta con un techo vegetal o con tejado a una o dos aguas. Como los corrales se iban agregando a otros ya existentes, el conjunto crecía desordenadamente, presentando una forma laberíntica (fig. 3).

El chozo en el que dormía el pastor que vigilaba los rebaños suele estar dentro del corral o a su entrada, unido a sus muros, aunque actualmente muchos han quedado aislados por haberse destruido los corrales para aprovechar la piedra o para labrar el monte. La mayoría de los chozos son de planta redonda, aunque no sea un círculo perfecto; se pueden dividir, según su alzado y sección, en dos grupos:

a) Chozos troncocónicos. Exteriormente son un perfecto tronco de cono, con los muros en talud construidos con mampuestos irregulares y como único vano una puerta muy estrecha y baja, con dintel monolítico, cuyas jambas se aproximan más por el interior que por el exterior, para resguardarse mejor del frío, pues nunca tenían puerta de madera. Dentro, como en todos los chozos, no había sino un camastro en el suelo de ramas secas y paja, y unas piedras en círculo para encender fuego, que podían estar en el centro si el chozo tenía abertura superior par salida de humos o junto a la puerta si no la tenía. Estos chozos son muy característicos de la comarca del Cerrato y zonas cercanas de Palencia, Valladolid y Burgos.

Su sección interna presenta dos variantes: en ojiva, lo más frecuente en las cúpulas de aproximación de hiladas (fig. 4); o piriforme, más rara, cuya cúpula suele estar levantada con piedras de mayor tamaño, como un ejemplar de Astudillo (fig. 5), que tiene solamente 16 hiladas.

Cuando los corrales están cerca de una ladera, el chozo puede construirse en ella, de manera casi subterránea y así aprovechar la protección del terreno (fig. 6).

Una forma más original es la que puede verse en un chozo troncocónico doble de Alba de Cerrato, cuya forma externa resulta de la superposición de dos troncos de cono; su interior es de una sola cámara (fig. 7; lám. I.a). Todos los chozos troncocónicos tienen un gran parecido con ciertas construcciones prehistóricas, como los talayotes o las nuragas. También en Bretaña hay tumbas megalíticas a las que se parece sorprendentemente el chozo doble que acabamos de ver (fig. 8).

b) Chozos elipsoidales. Tienen exteriormente la misma forma elipsoidal del interior. No son un grupo homogéneo sino que hay muchas variantes, según su altura fundamentalmente. Los hay esbeltos, de casi seis metros de altura, como el que se levanta en Cogeces del Monte 


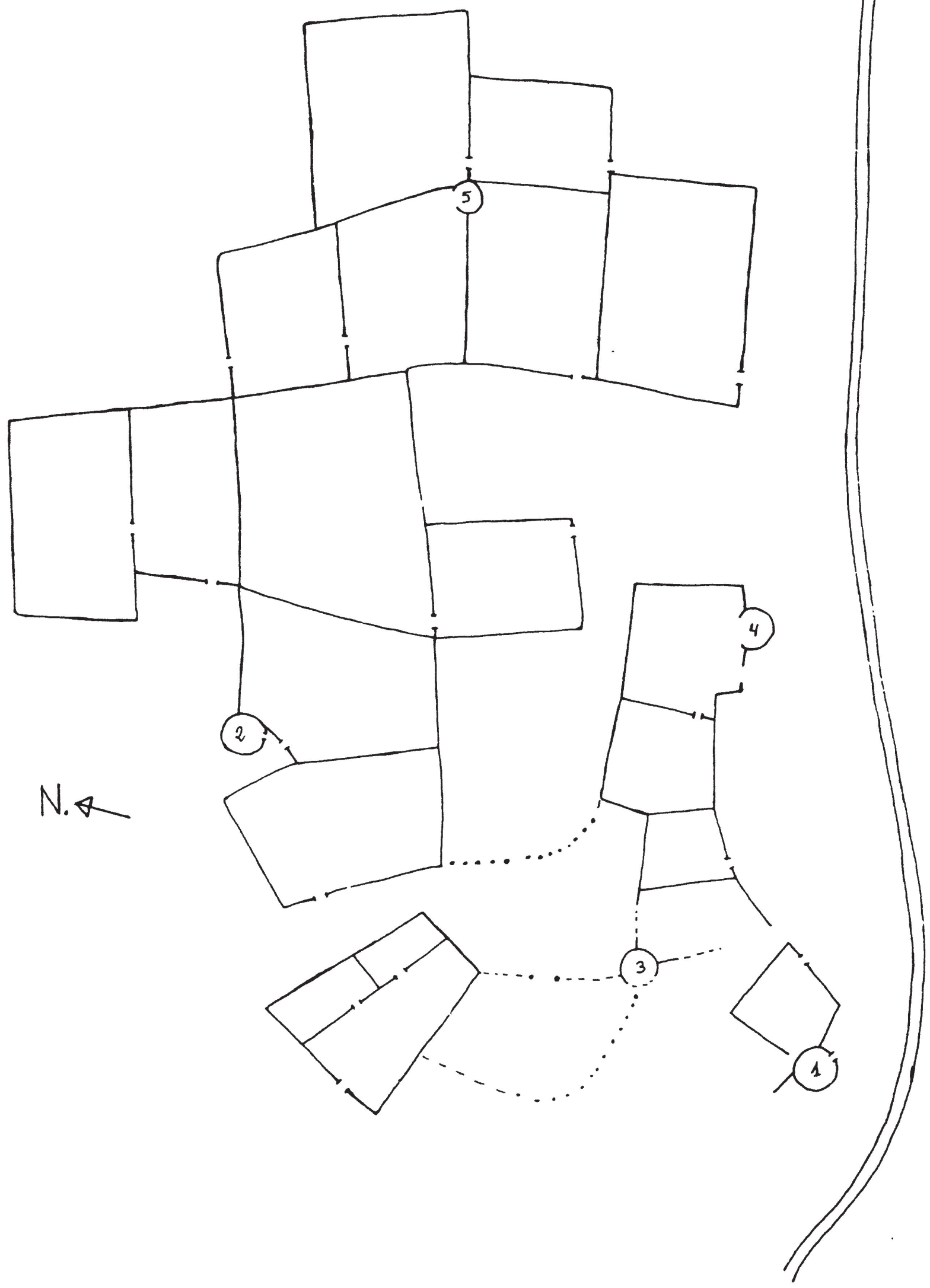

FIG. 3.-Croquis de unos corrales de Alba de Cerrato (Palencia). De 1 a 5 son chozos. El núm. 1 es el chozo doble de la fig. 7 y el 2 el de la fig. 11, los otros tres están arruinados. 

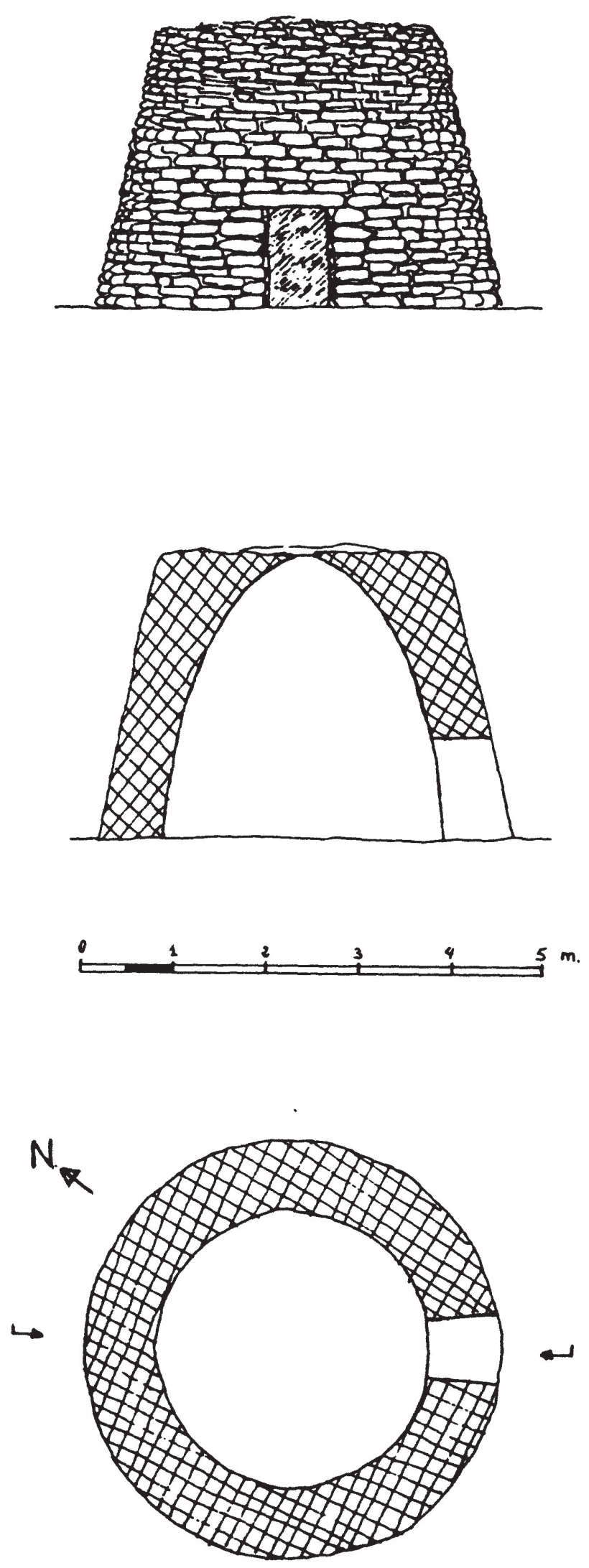

FIG. 4.-Chozo de Villabáñez (Valladolid). 

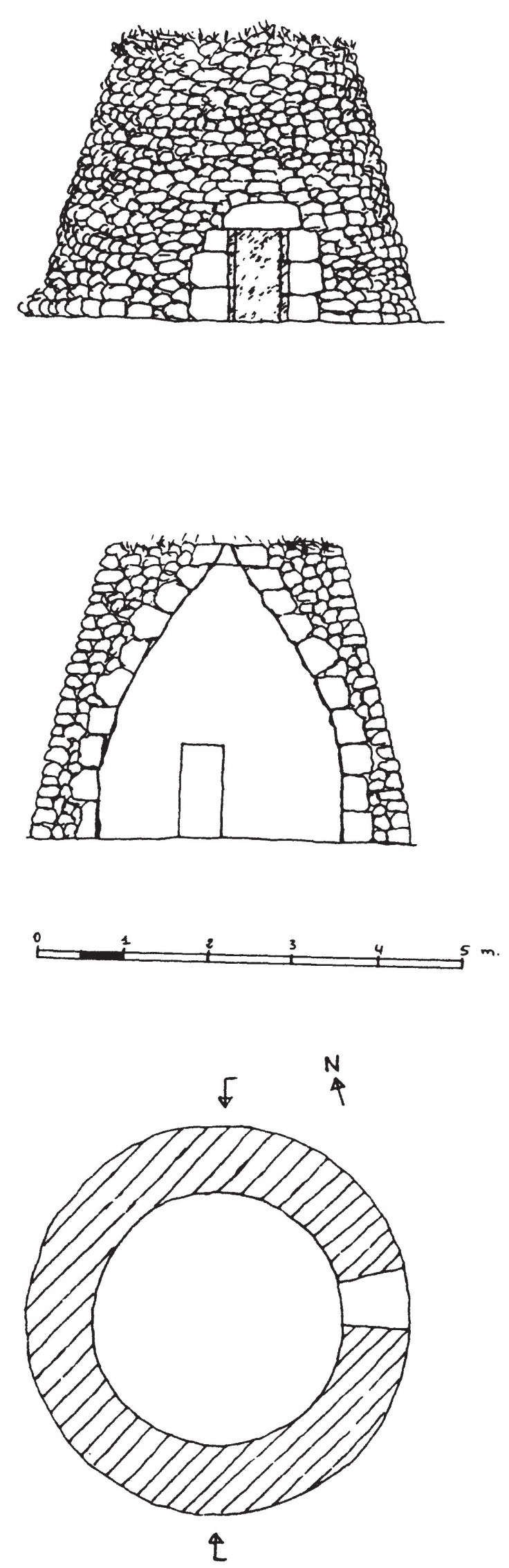

FIG. 5.-Chozo de Astudillo (Palencia). 

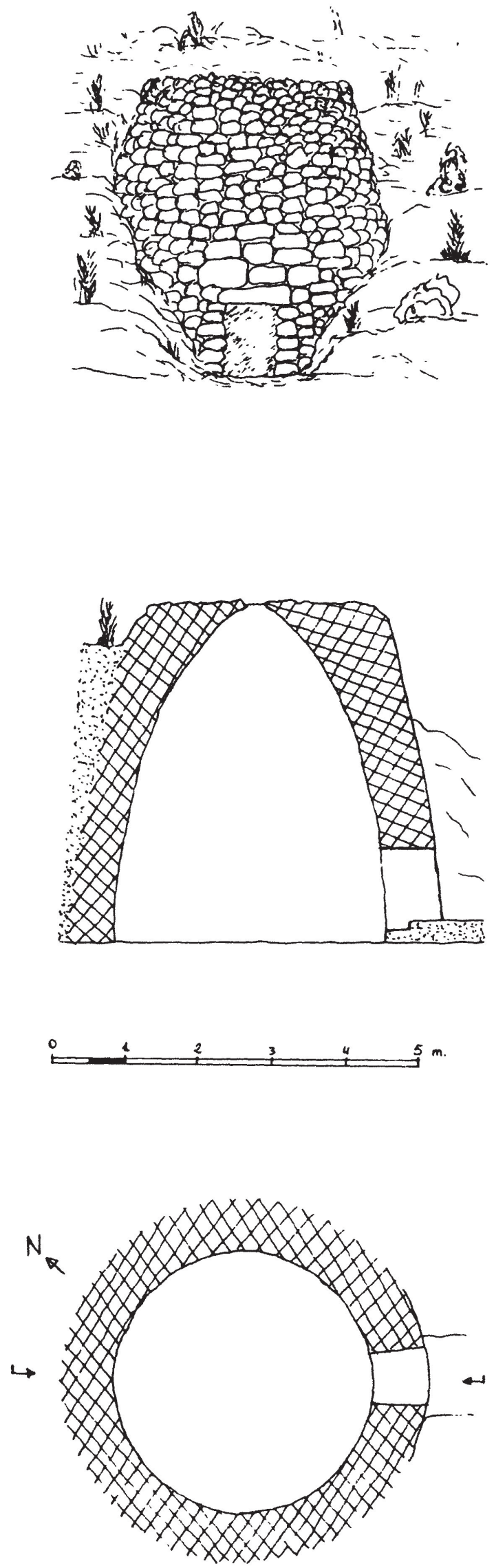

Fig. 6.-Chozo semisubterráneo de Villabáñez, cercano al de la fig. 4. 

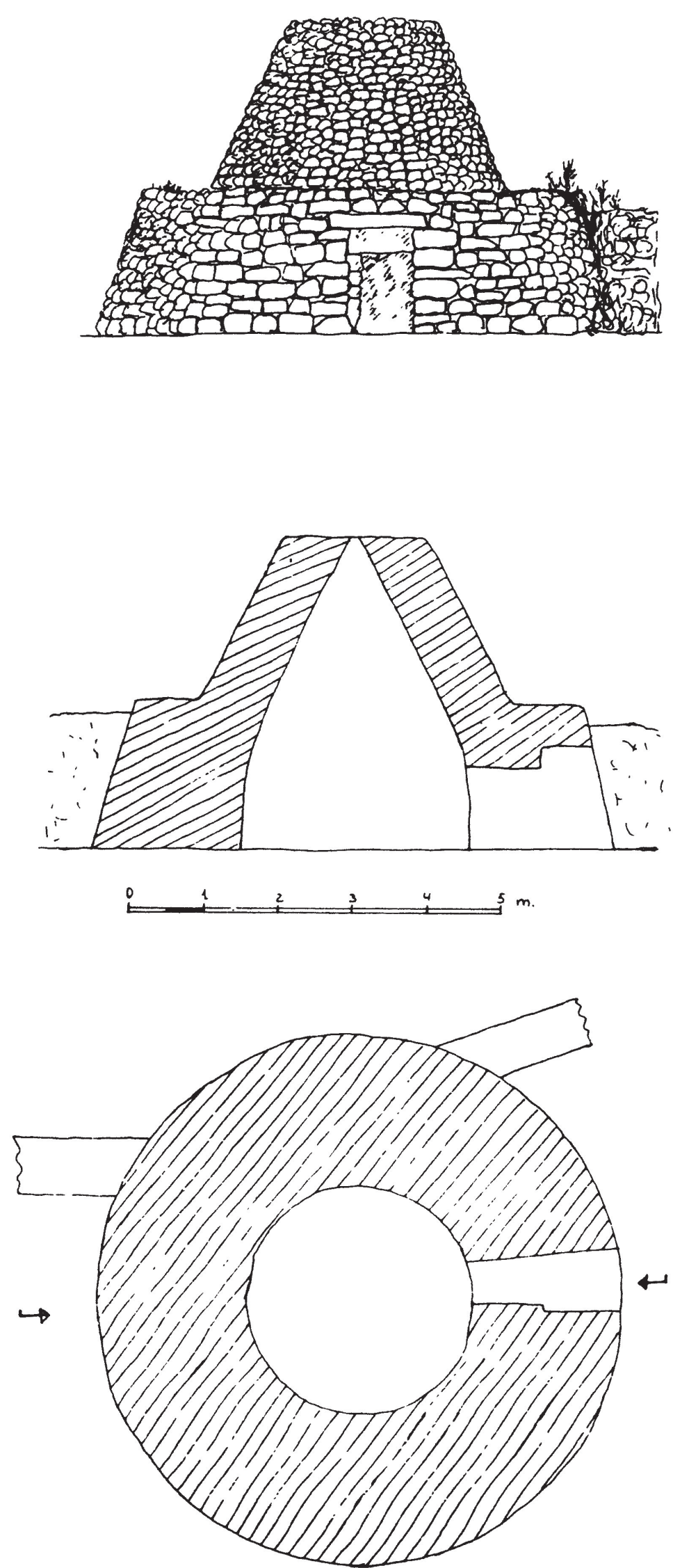

Fig. 7.-Chozo doble de Alba de Cerrato. Cf. fig. 3. 


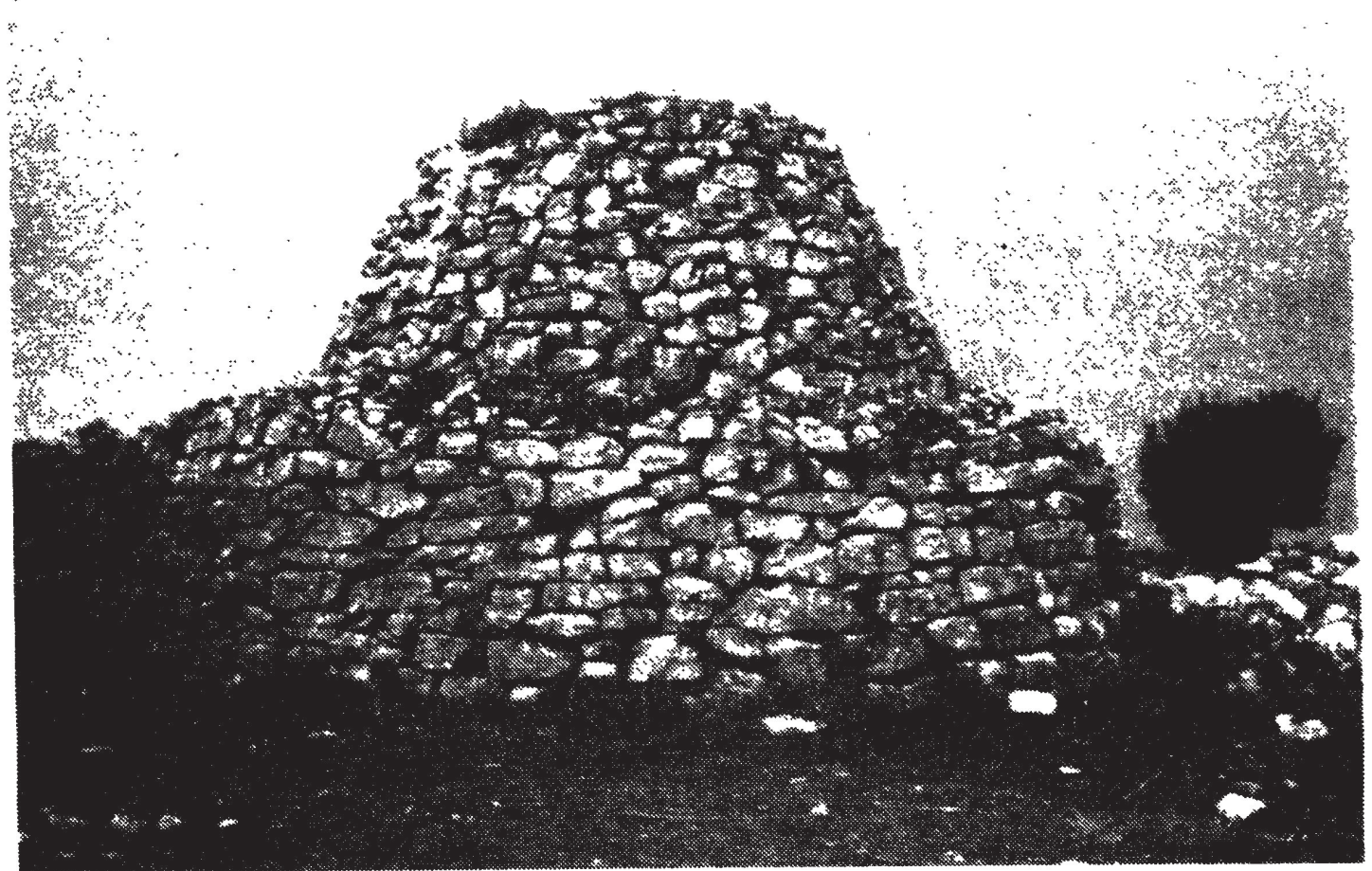

LÁm. I.a._Chozo de Alba de Cerrato (Palencia).

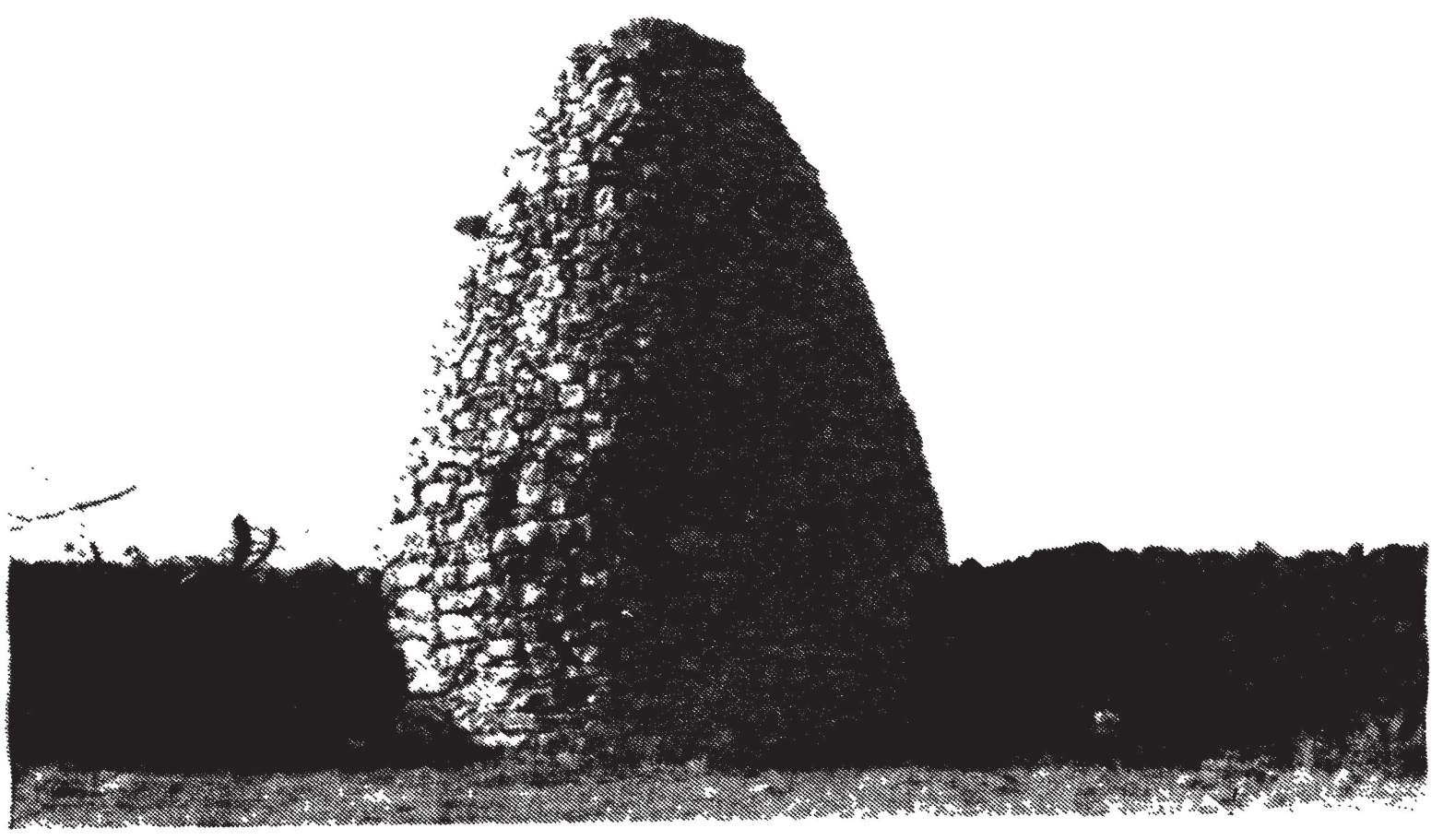

LÁM. I.b.-Chozo de Cogeces del Monte (Valladolid). 

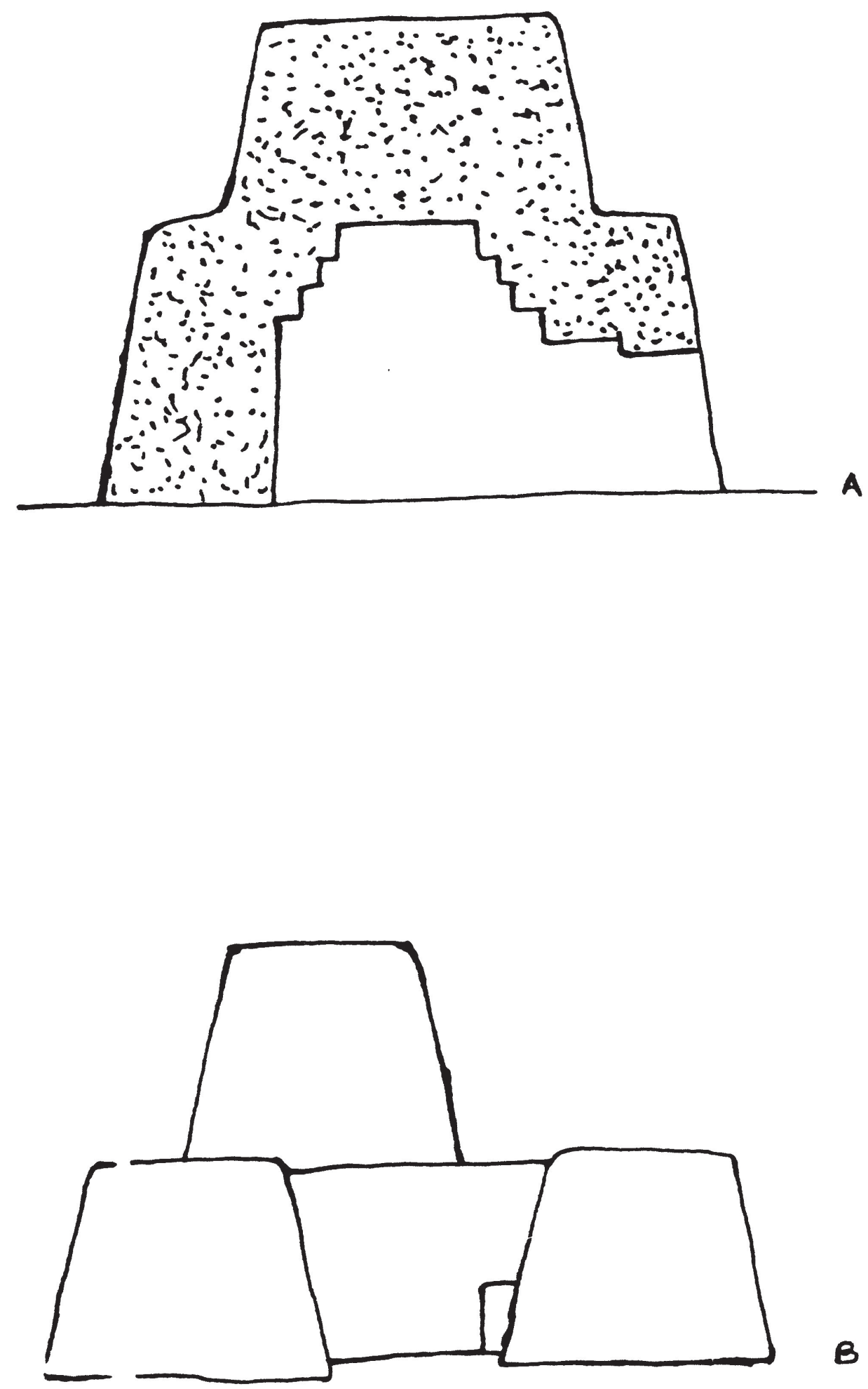

FIG. 8.-a) Tumba megalítica de Er-Maneco (Bretaña), según Renfrew. b) Nuraga de Palmavera. 
(Valladolid), al borde de un páramo frente a las ruinas del monasterio de La Armedilla (fig. 9; lám. I.b), cuya abertura superior se cubre con dos piedras colocadas en forma de $\mathrm{v}$ invertida (fig. 10), procedimiento que también se usa en ciertos casos para los huecos. Otros son achaparrados, con su parte superior aplanada y, en ocasiones, recubierta de tierra y céspedes para mejor protegerse de la lluvia. El ejemplo de Alba de Cerrato tiene unas paredes muy gruesas (fig. 11) y aspecto externo macizo; el de Valoria del Alcor (fig. 12) es más esbelto y, cuando tenía su remate de céspedes, la forma era semiesférica. Estos dos chozos no tienen abertura superior, sino que la bóveda se cierra con unas cuantas piedras verticales (fig. 10), por lo que se rompe el principio de horizontalidad de la falsa cúpula.

Además de los chozos de planta circular, hay otros de planta ovalada o parecida a un polígono irregular, aunque con los ángulos redondeados. El de la (fig. 13) está en la llanura de monte bajo que hay entre Vilaseca y el monasterio de San Frutos de Duratón (Segovia); sus dimensiones son humildes, los muros muy gruesos para la poca altura y la cúpula está hecha con lajas delgadas. Está coronado por una piedra en forma de hacha con su corte hacia el cielo, para que lo protegiera de los rayos; una piedra puntiaguda que mira al cielo es muy frecuente en la coronación de casetas de era, pozos y zarceras. El de la fig. 14 tiene planta parecida a un pentágono y su cúpula de forma apuntada está cerrada con piedras verticales.

\section{Caseta de era}

Con el nombre de casetas se conocen en muchas zonas de Castilla y de León las construcciones que en las eras servían para guardar los aperos y pernoctar o dormir la siesta durante la temporada de la trilla (lám. II.a). Algunas son de gran tamaño y tienen cuadra para las caballerías de trabajo; también son muchas las que poseen pozo, bien en su interior, bien fuera de ellas. En la mayor parte de la región estas casetas se cubren con tejado a dos o cuatro aguas; pero hay una amplia zona que comprende los Montes de Torozos - extenso páramo que separa el valle del Pisuerga de las llanuras de Tierra de Campos- y las campiñas meridionales de esta última en la que abundan las casetas de planta circular o cuadrangular cubiertas con falsa cúpula (fig. 15).

a) Casetas de planta cuadrada. son las que más abundan, como se puede observar en el mapa de la fig. 15, mientras que las de planta circular se sitúan en un pequeño espacio meridional de la zona delimi- 

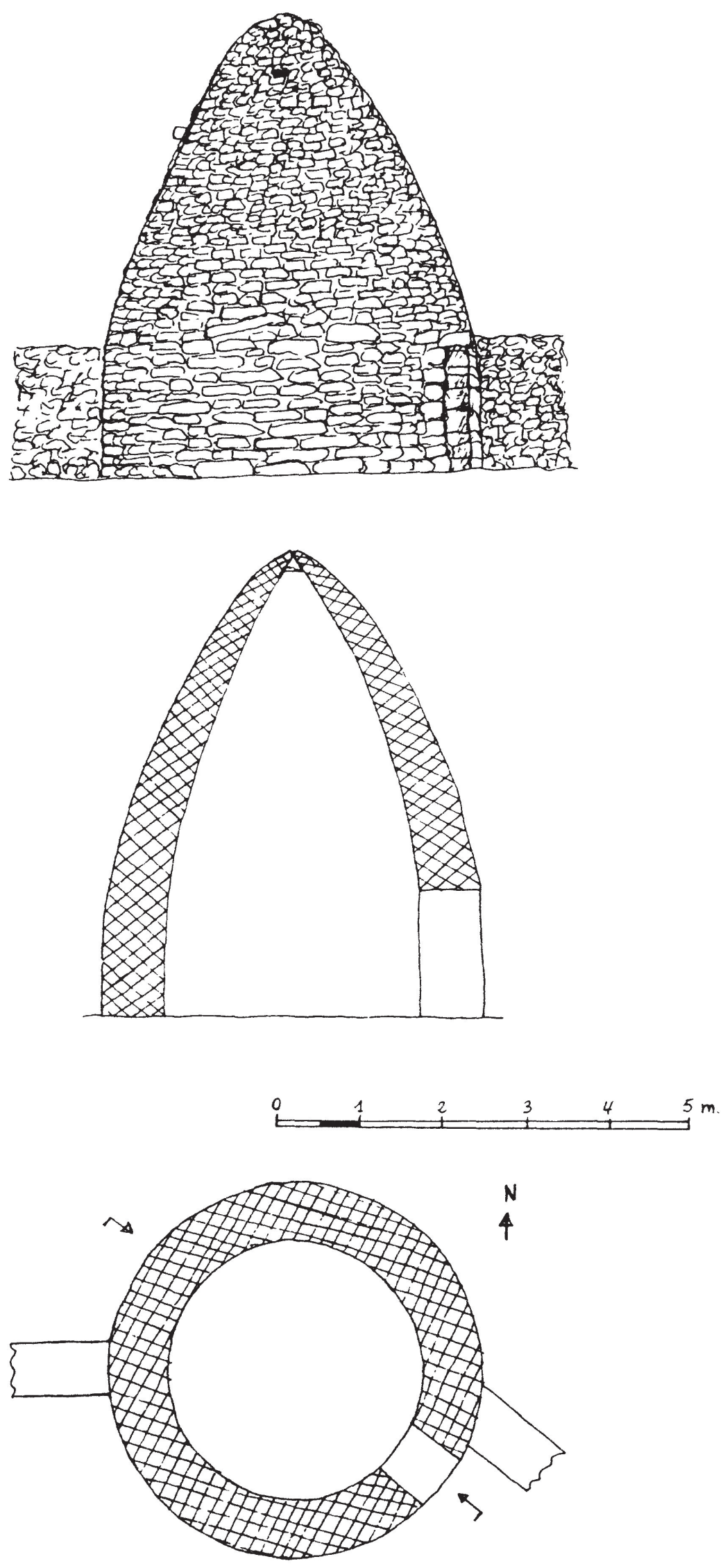

FIG. 9.-Chozo de Cogeces del Monte (Valladolid). 

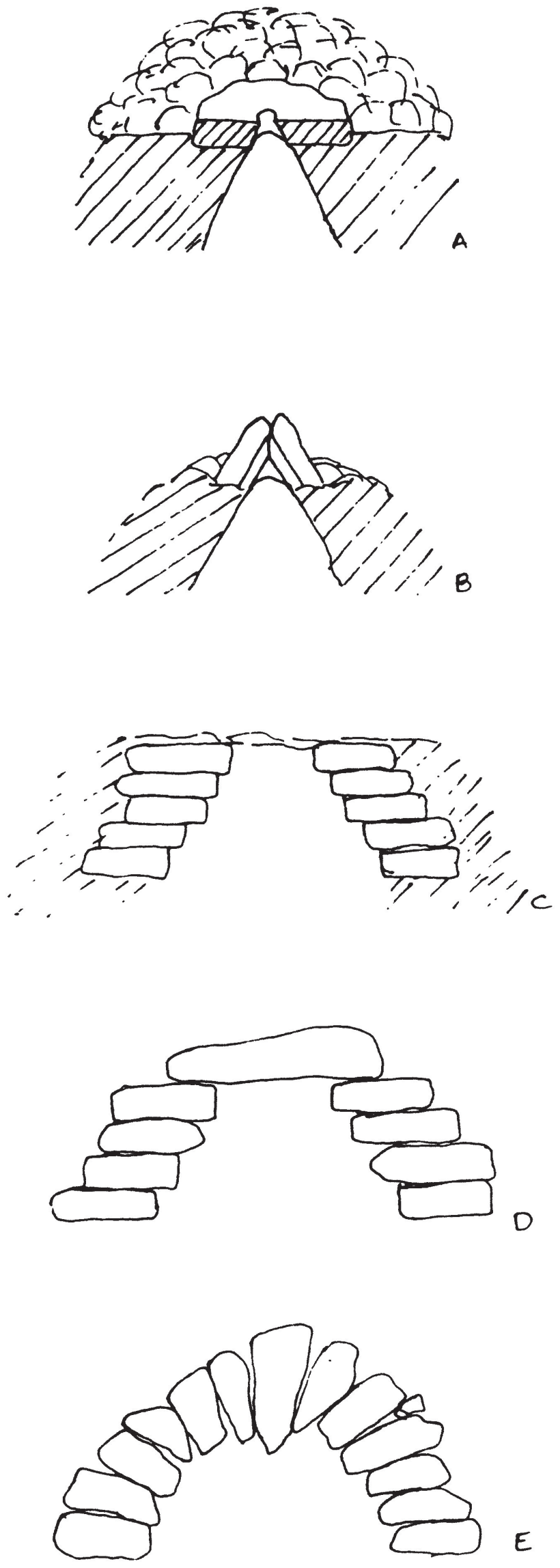

FIG. 10.-Formas de cerramiento de la cúpula de los chozos pastoriles. a) Losa con agujero para salida de humos. b) Dos piedras planas colocadas en v invertida. c) Cúpula sin cerrar. d) Losa sin agujero. e) Mampuestos verticales. 

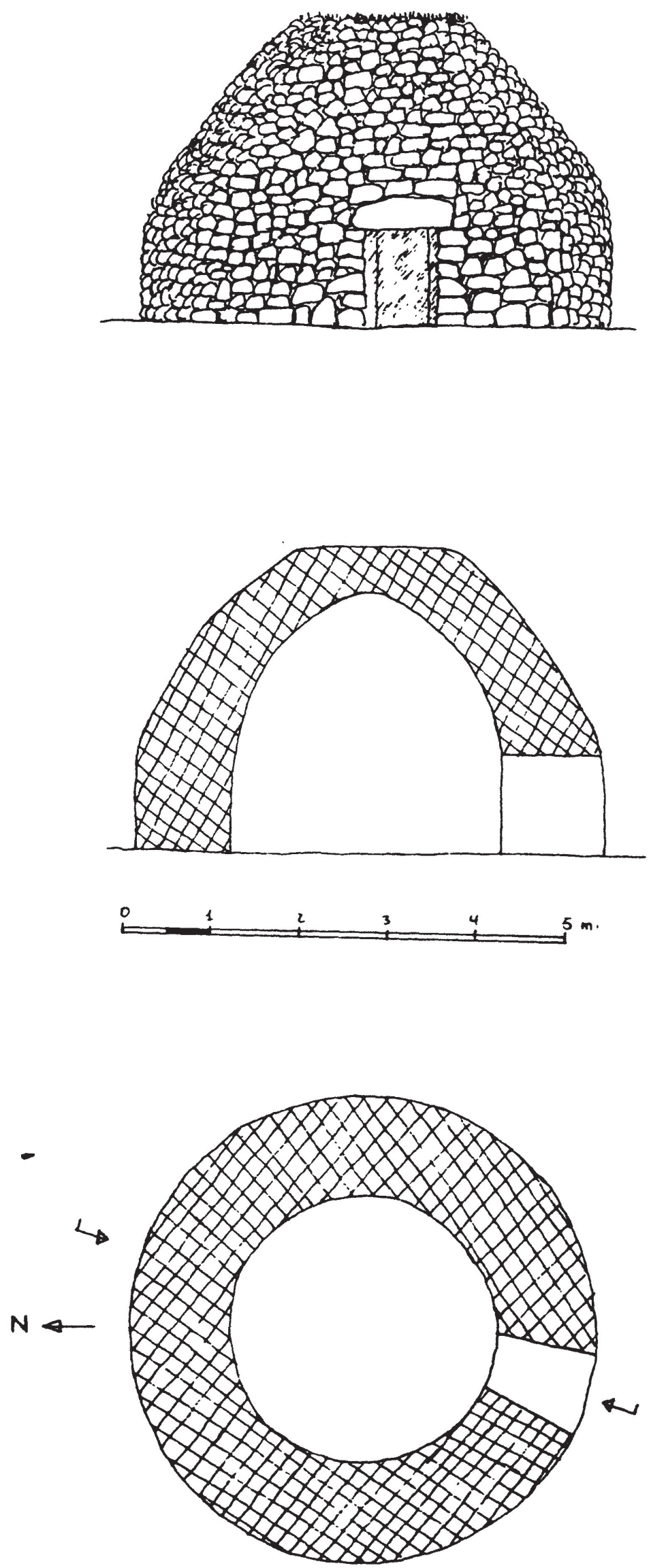

Fig. 11.-Chozo de Alba de Cerrato. Cf. fig. 3. 

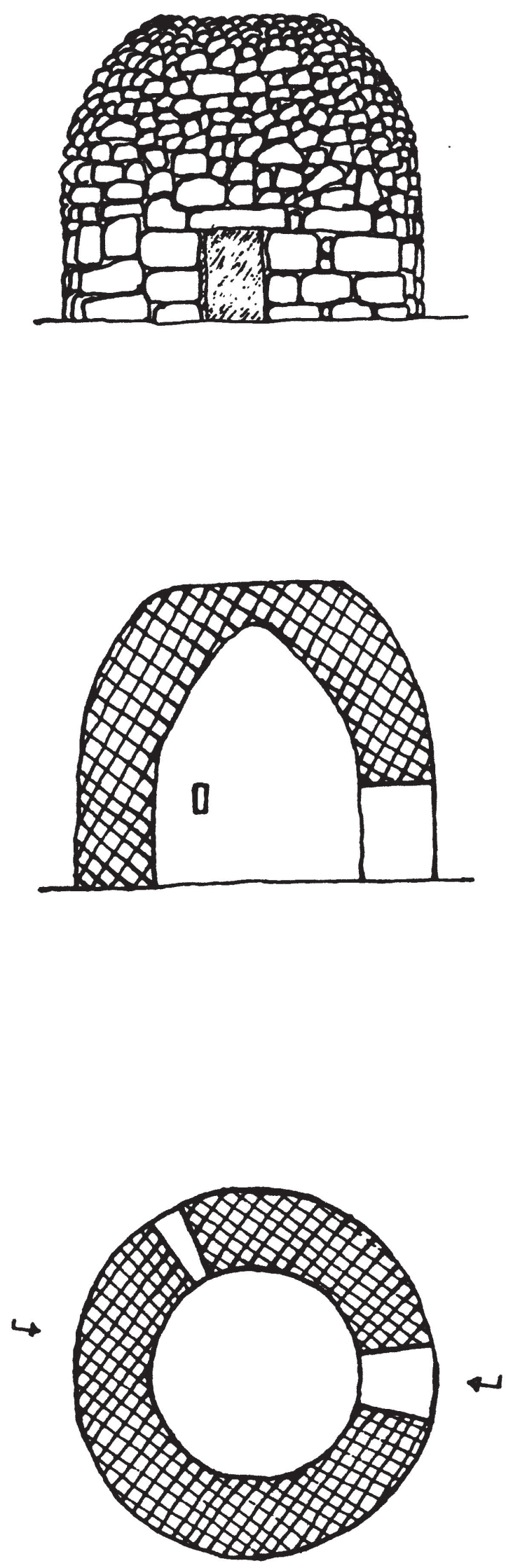

Fig. 12.-Chozo de Valoria del Alcor (Palencia). 

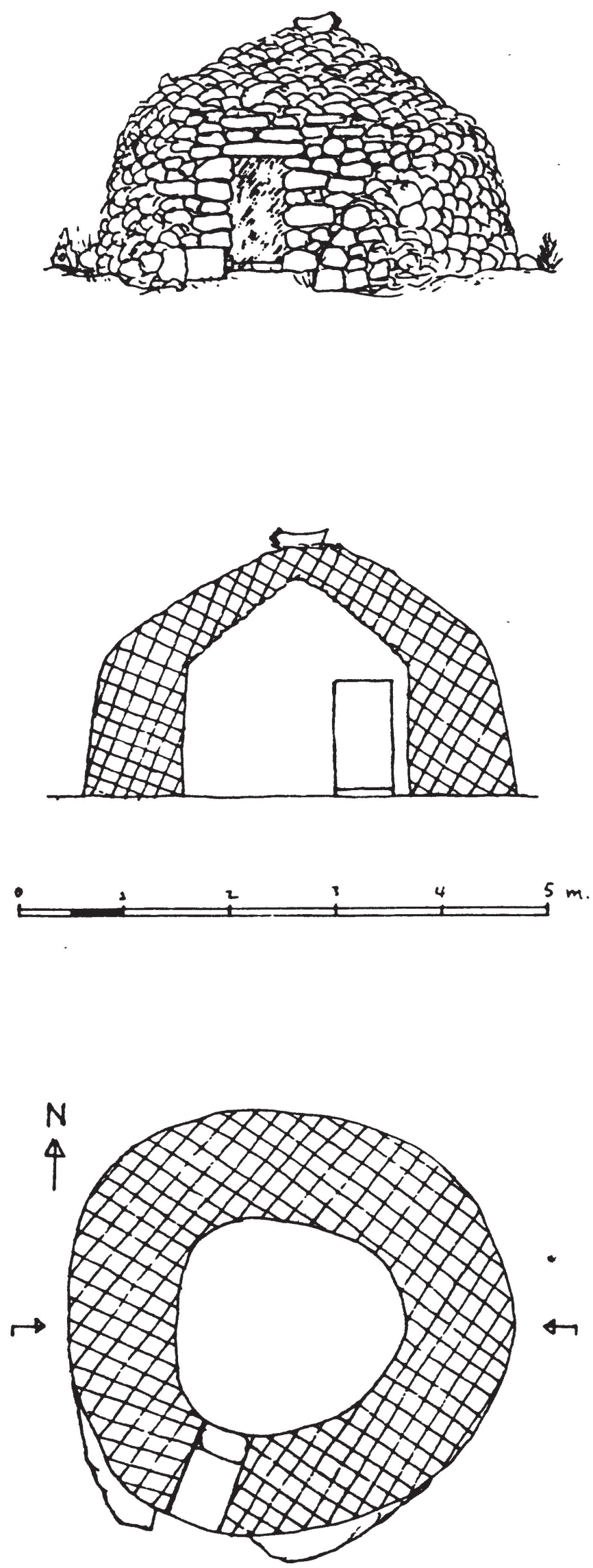

Fig. 13.-Chozo de Villaseca (Segovia). 

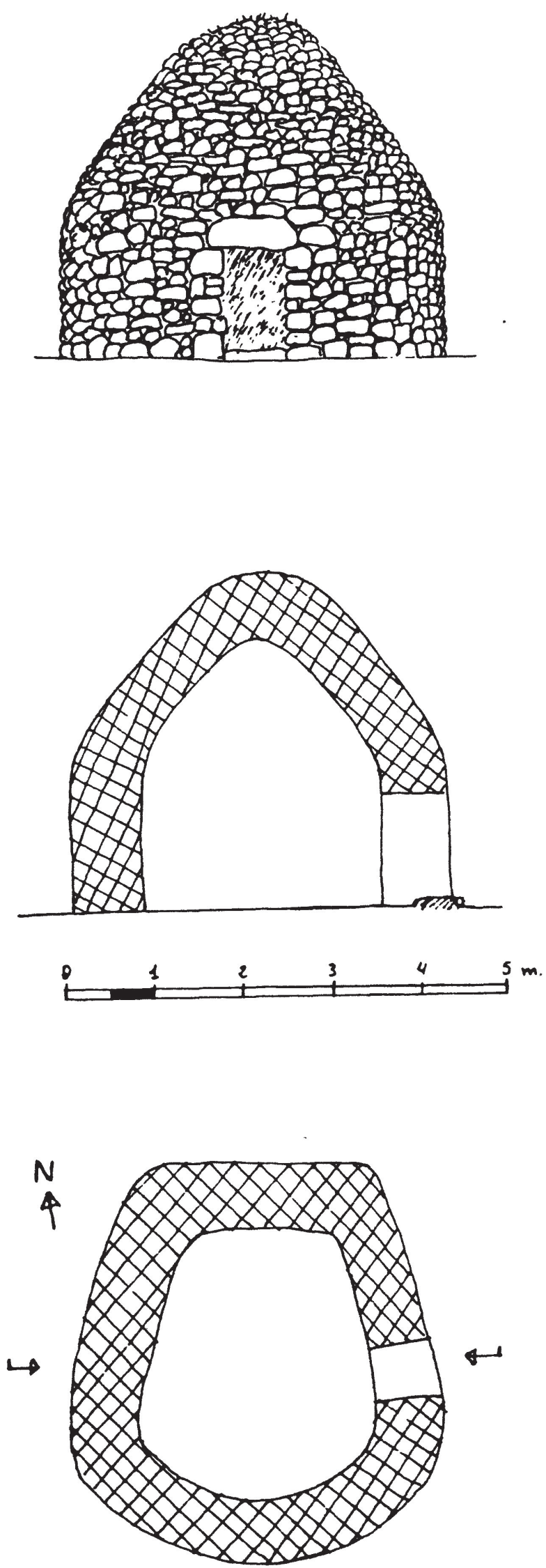

FIG. 14.-Chozo de Aranda de Duero (Burgos). 


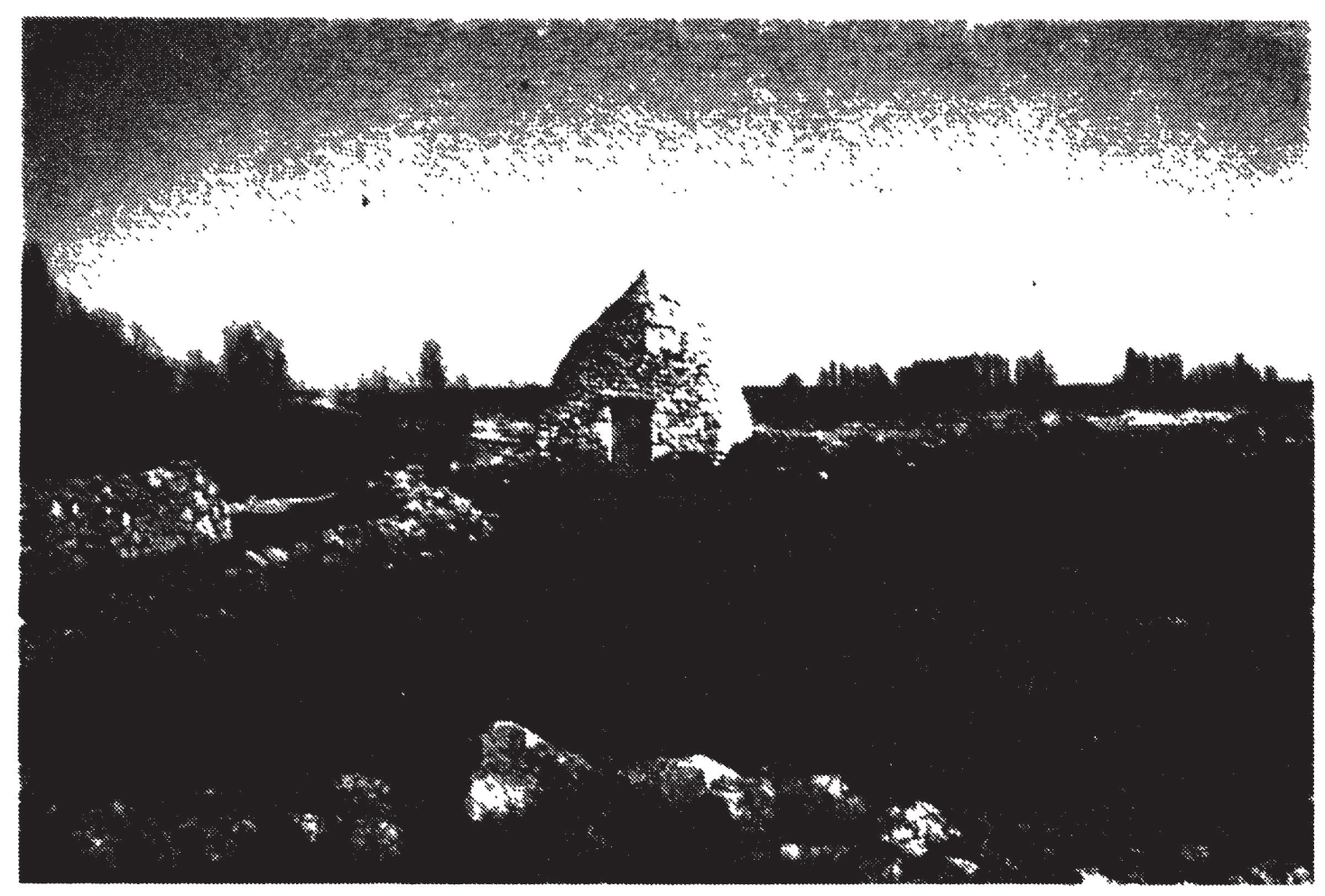

LÁM. II.a.-Era con caseta en Castromonte (Valladolid).

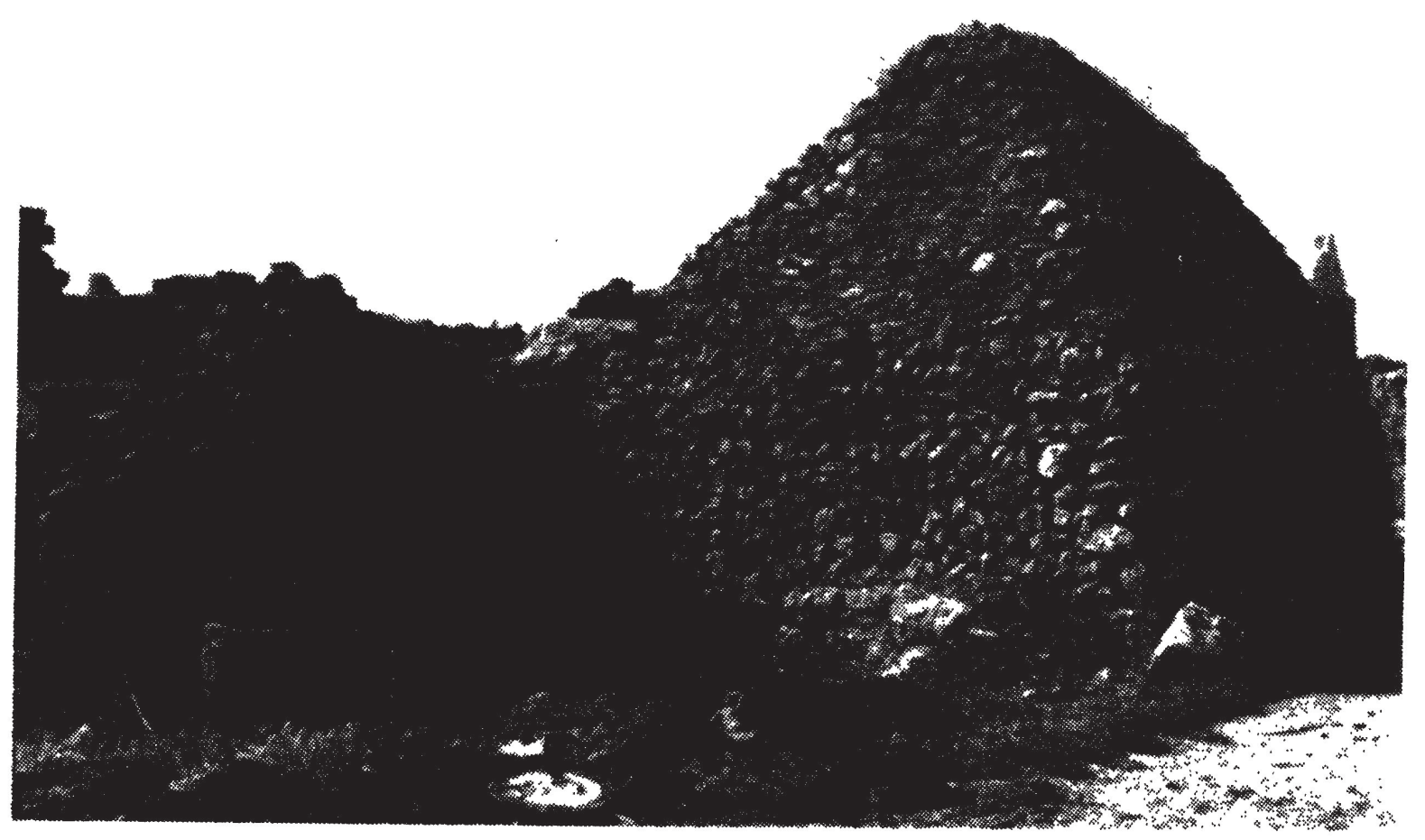

LÁM. II.B.-Caseta con pozo adosado en Peñaflor de Hornija (Valladolid). 


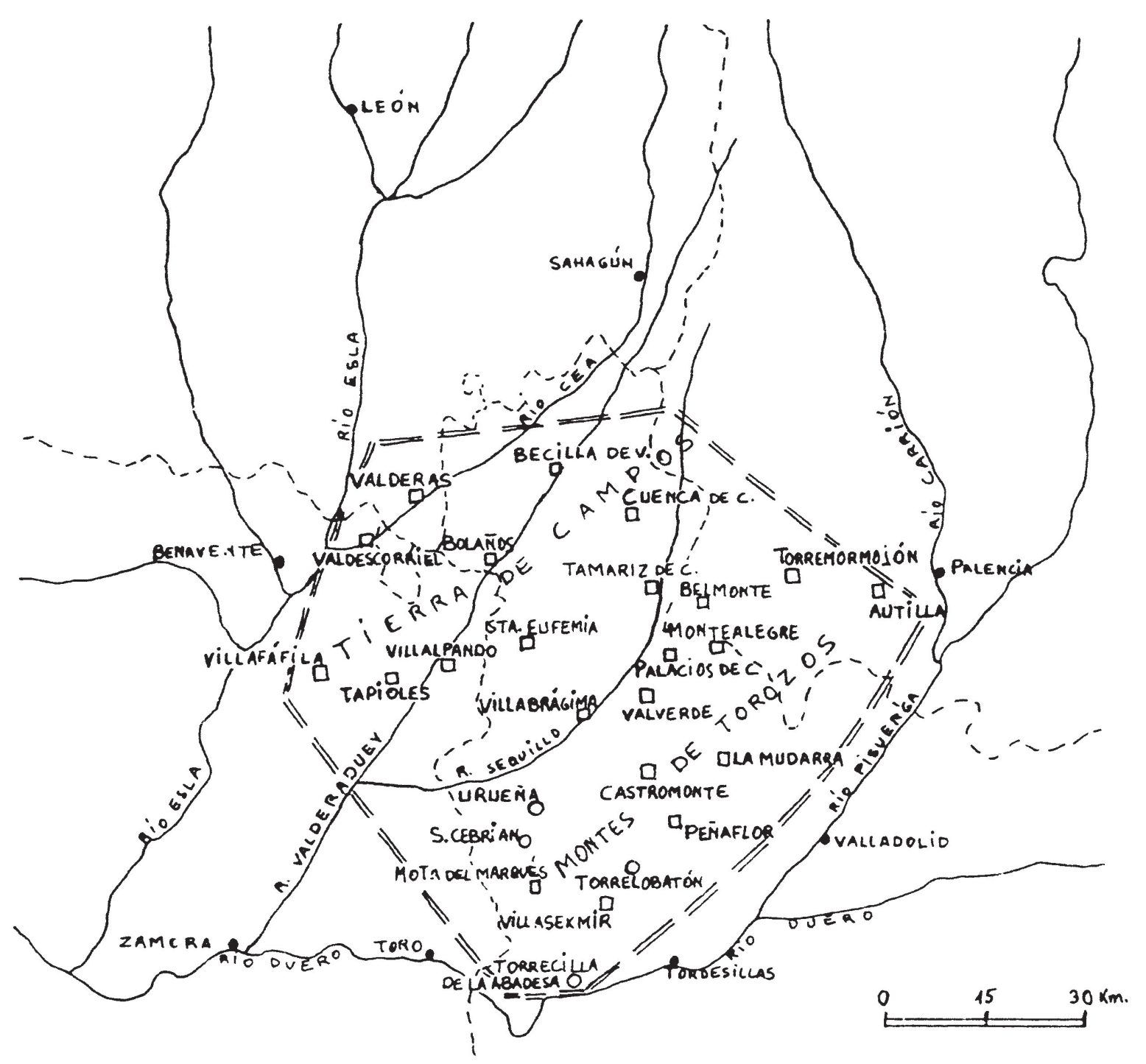

FIG. 15.-Localización de las comarcas en que abundan las casetas de era. Los cuadros y círculos indican planta cuadrada y redonda respectivamente. 
tada. Según los materiales con que están construidas se pueden clasificar en tres tipos:

\section{De piedra.}

2. De piedra y adobe.

3. De adobe.

1. Comenzaremos con las que están construidas con la piedra caliza propia de los Torozos. Su planta es un cuadrado no siempre exacto, de unos tres metros de lado en el interior. Los muros son normalmente de mampostería muy basta, trabada con barro, aunque en Montealegre hay algunas de toscos sillares; el grosor es de setenta u ochenta centímetros y a veces presentan exteriormente un poco de talud (fig. 16).

Como todo edificio cuadrado que se cubra con cúpula, tienen que solucionar el paso del cuadrado al círculo y lo hacen de diferentes formas. Una es cerrar los cuatro ángulos desde la base, convirtiendo la planta cuadrada en octogonal en el interior, como vemos en algunos ejemplares de Montealegre, cuya cúpula algo apuntada va recubierta externamente de losas calizas mal ensambladas (fig. 17). La solución normal es la de utilizar trompas. Son grandes piedras planas colocadas sobre los ángulos que forman los muros; en las casetas de piedra y adobe suelen ser de madera. Otra solución es el empleo de pechinas, conseguidas con mampuestos que sobresalen progresivamente (fig. 16).

La falsa cúpula tiene forma elipsoidal; en algunas el perfil es muy esbelto, casi piramidal. Puede estar cerrada por una losa circular, como sucede en el ejemplo de Montealegre, o por mampuestos colocados verticalmente, como en Castromonte, y rematada exteriormente por un pináculo de piedra.

En ocasiones la caseta tiene aneja una pequeña construcción circular para alojar el pozo (lám. II.b).

2. También en la comarca de Torozos y algunos pueblos cercanos de Tierra de Campos encontramos un tipo de caseta con los muros de piedra y la cúpula de adobe. Las trompas pueden ser de piedras o de madera. La falsa cúpula de adobe, generalmente apuntada, es de un asta (fig. 18) o de media asta (fig. 19). Esta última, de Mota del Marqués, tiene una pared de piedra muy baja y una cúpula muy apuntada que arranca a la altura de metro y medio y alcanza más de cuatro; está adosada a otra cubierta con tejado a una vertiente que servía de cuadra.

Estas cúpulas de adobe suelen estar revocadas de barro mezclado con paja, para evitar la erosión; este revoque se renovaba casi todos los años. El abandono de esta labor ha provocado la ruina de muchas de estas bóvedas. 

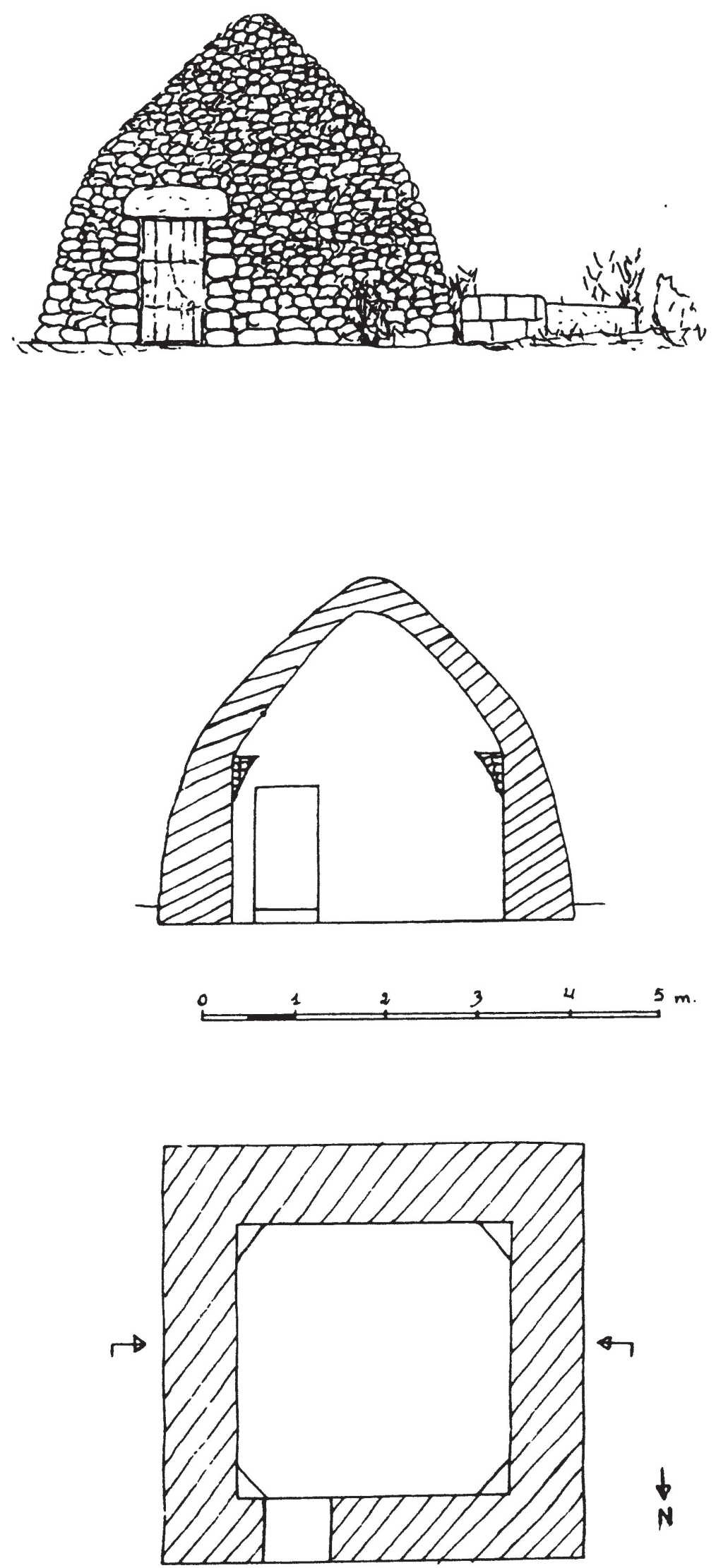

FIG. 16. - Caseta de Castromonte (Valladolid), de planta cuadrada con pechinas. En dicho pueblo se llaman chozos. 

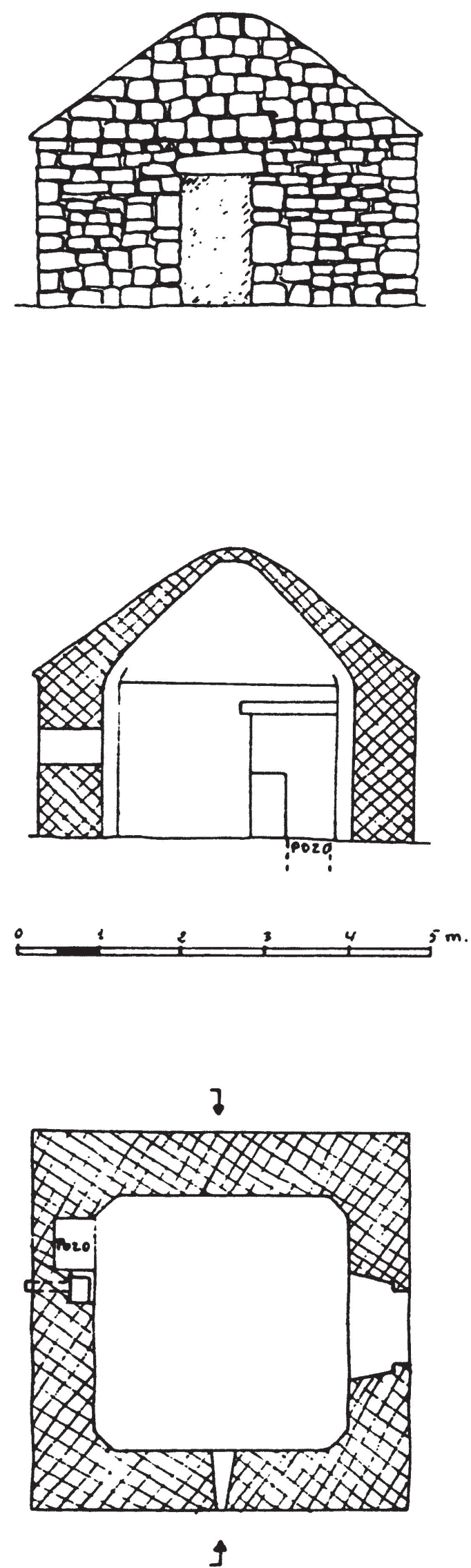

Fig. 17.-Caseta de Montealegre (Valladolid), de planta' ochavada en su interior. Tiene pozo cegado. 

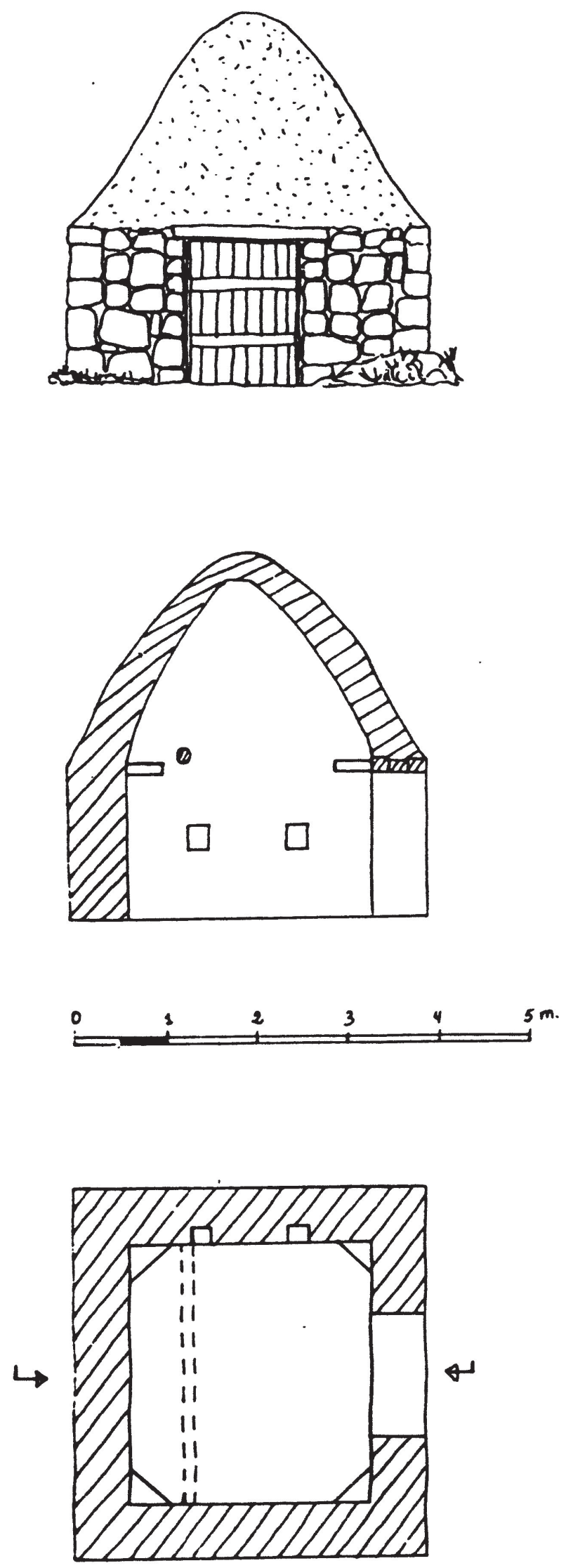

Fig. 18. - Caseta en las eras de Villasexmir (Valladolid), con muros de piedra y cúpula de adobe a una asta. Las trompas son una piedra caliza plana. 

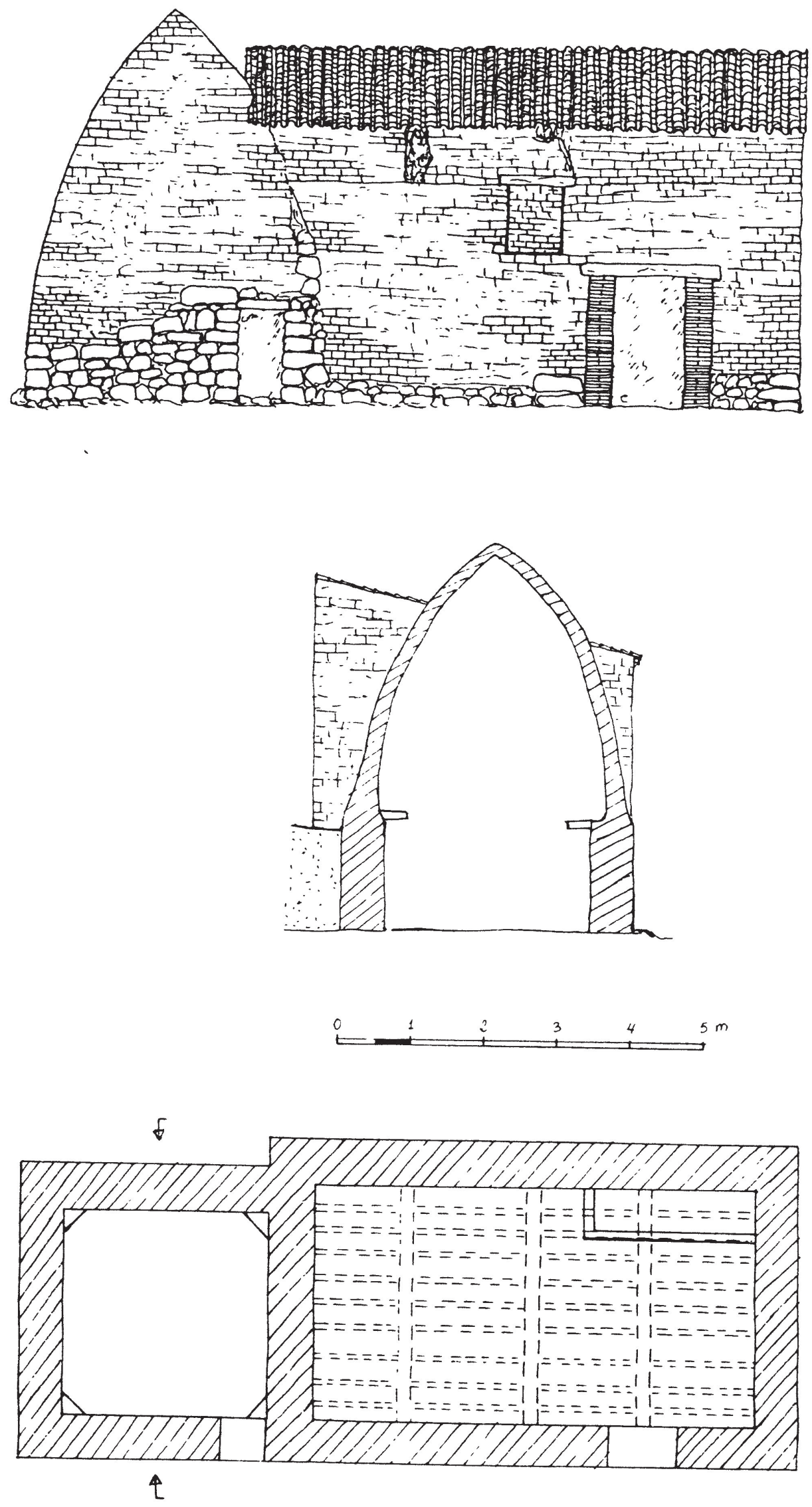

FIG. 19.-Caseta de Mota del Marqués (Valladolid), con cúpula de adobe a media asta. Está adosada a otra con tejado que servía de cuadra. 
Un tipo distinto es el de las cúpulas casi semiesféricas, parecidas a las bóvedas de los hornos. No son realmente falsas cúpulas, porque los adobes de la parte superior están colocados verticalmente (fig. 20), aunque se construían sin cimbra al ser su diámetro pequeño. Para mejor protegerlas de la lluvia, en vez de revoque de barro, en ocasiones, se recubrieron de piedras (fig. 21), a pesar de lo cual la mayoría de ellas están en mal estado de conservación (lám. III.a).

3. Finalmente en Tierra de Campos las casetas son totalmente de barro. Lo normal es que los muros sean de tapial, de medio metro de ancho, y la cúpula de adobe, de media asta, revocada de barro con paja. Las trompas son siempre de madera y las bóvedas apuntadas, de unos dos metros y medio de altura (fig. 22), pero las hay también como las de los hornos (fig. 23; lám. III.b).

Algunas casetas presentan rasgos peculiares, producto de la adaptación al espacio disponible o a las necesidades de los usuarios, la de la figura 24 presenta una planta poligonal irregular, que obligó a sus constructores a levantar un gran lomo de barro para rellenar el ángulo agudo. En Tamariz de Campos la planta rectangular se cubre con dos o tres cúpulas (fig. 25).

b) Casetas de planta circular. Son pocas las muestras que conocemos, aunque la variedad formal no es menor que en las cuadradas. En primer lugar, las hay totalmente de piedra, como el ejemplo de San Cebrián de Mazote (fig. 26), de grandes dimensiones y semejante a ciertos chozos pastoriles elipsoidales; su parte superior se reparó con adobe o quizás se construyó así. Otras tienen cúpula semiesférica, como la de Montealegre (lám. IV.a), cuya clave es una muela de molino.

De piedra y adobe podemos contemplar distintos ejemplares de «chozos» en Urueña; unos tienen cúpulas apuntadas de media asta sobre un muro más grueso de piedra (fig. 27); otros presentan una bóveda de horno sobre el mismo tipo de muro (fig. 28). Algunos están adosados a casetas de planta rectangular y tejado (lám. IV.b).

En un tercer grupo podemos incluir las de adobe como la arruinada de Torrelobatón (fig. 29), aunque tiene un basamento de una hilada de piedra que aísla los adobes del suelo. Más esbeltas y bien conservadas son las de las eras de Torrecilla de la Abadesa (fig. 30), cuyas paredes se protegen con trozos de tejas en las zonas azotadas por la lluvia. 

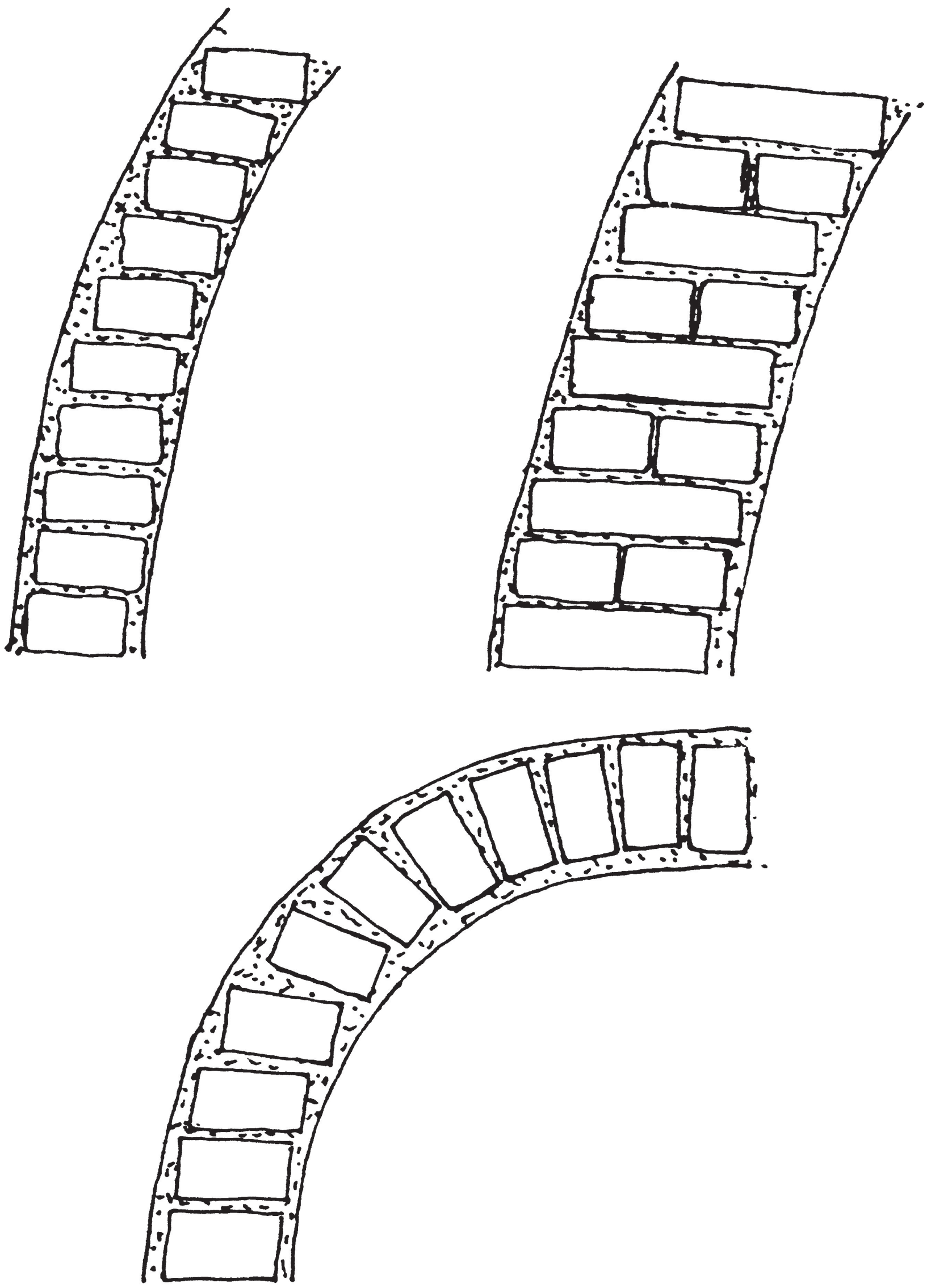

Fig. 20.-a) En la falsa cúpula los adobes, a media o a una asta, se colocan paralelos al suelo. b) Las bóvedas tipo horno se cierran con adobes perpendiculares a la base, por lo que sus empujes son oblicuos como los de las cúpulas «auténticas». 

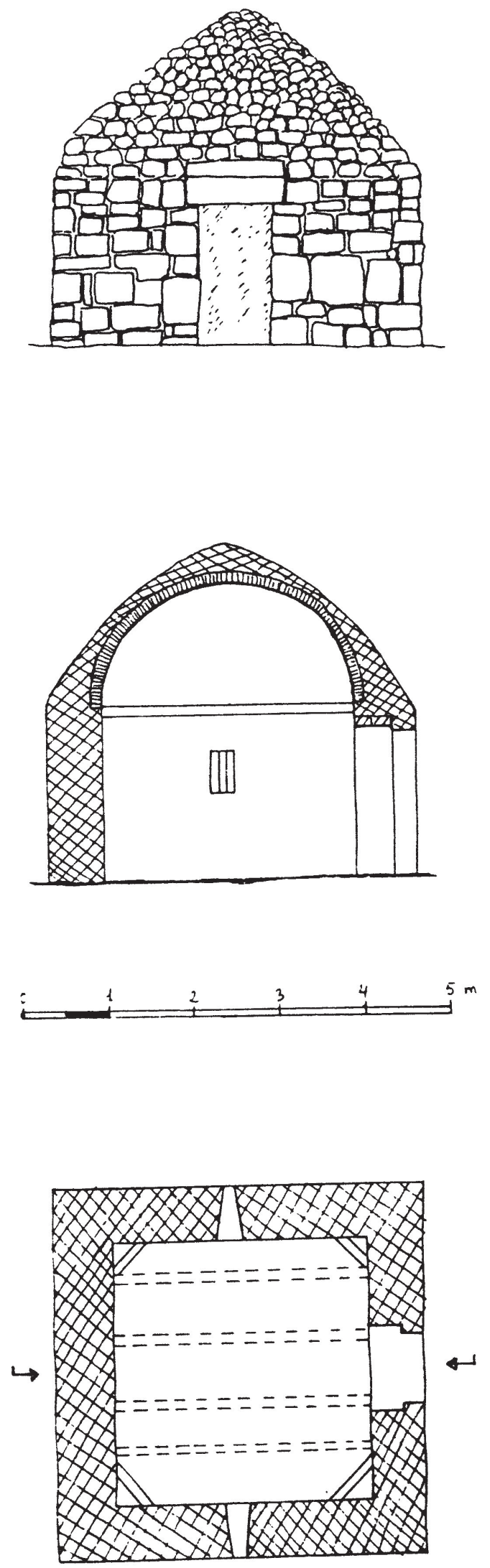

Fig. 21.-Caseta de Montealegre, de muros de piedra y cúpula casi semiesférica de adobe, recubierta con mampuestos. 


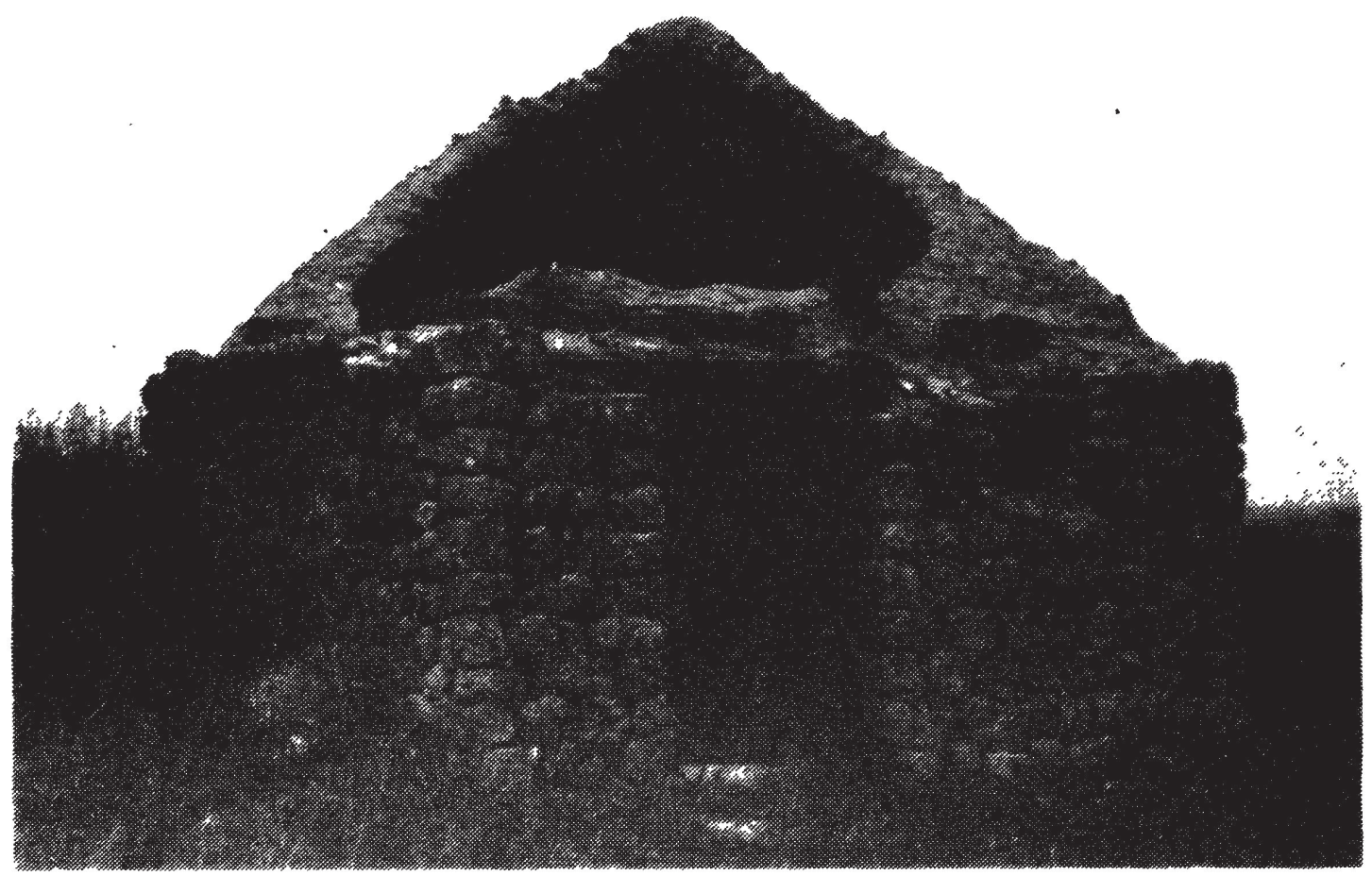

LÁM. III.a.-Caseta de Torremormojón Palencia).

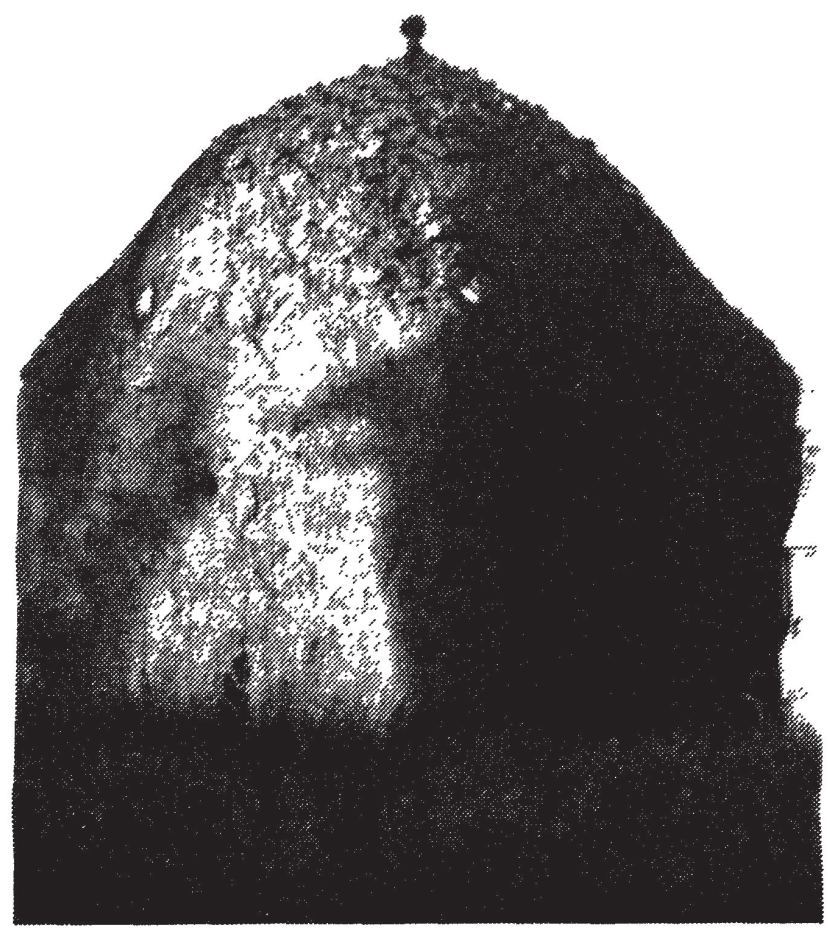

LÁM. III.b.-Caseta de tapial y adobe, con cúpula semiesférica, Cuenca de Campos (Valladolid). 

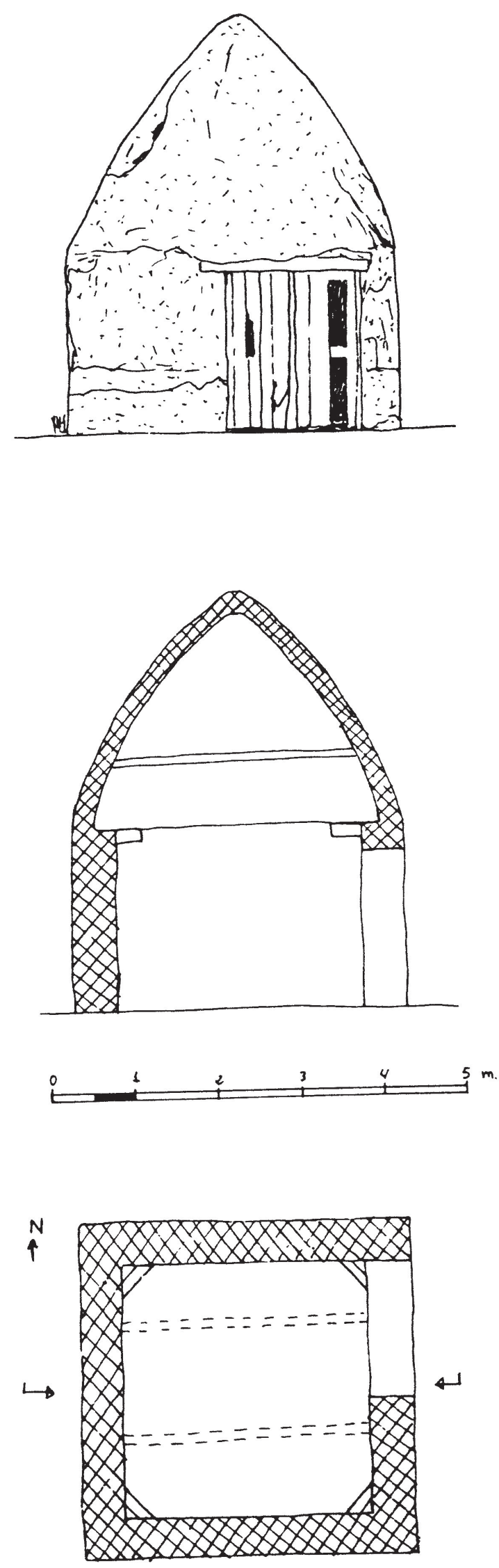

Fig. 22. - Caseta de las eras de Tapioles (Zamora), de muros de tapial, cúpula apuntada de adobe a media asta y trompas de madera. 

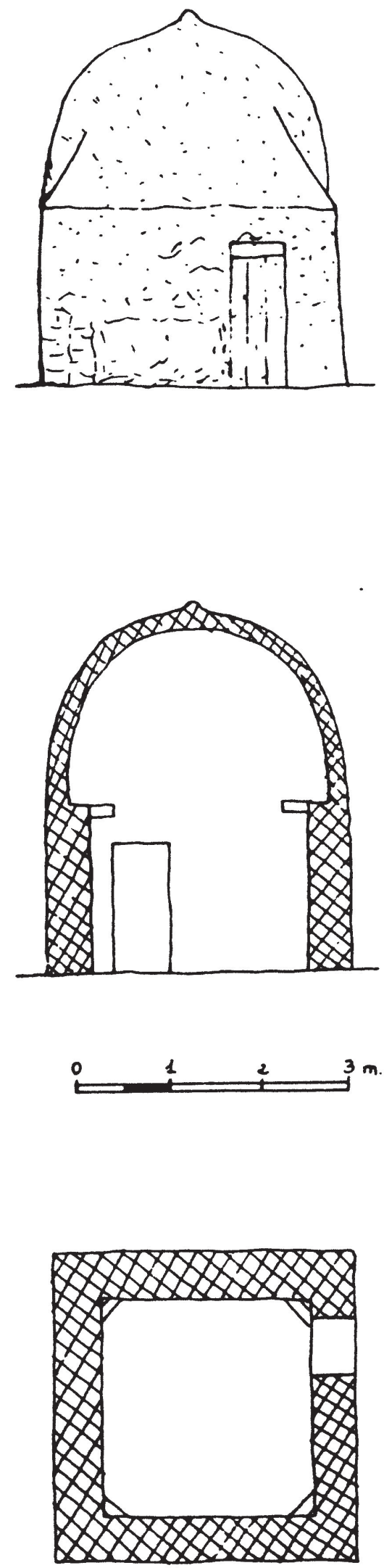

Fig. 23.-Caseta de Villafáfila (Zamora), semejante a la anterior pero con cúpula semiesférica, tipo horno. 

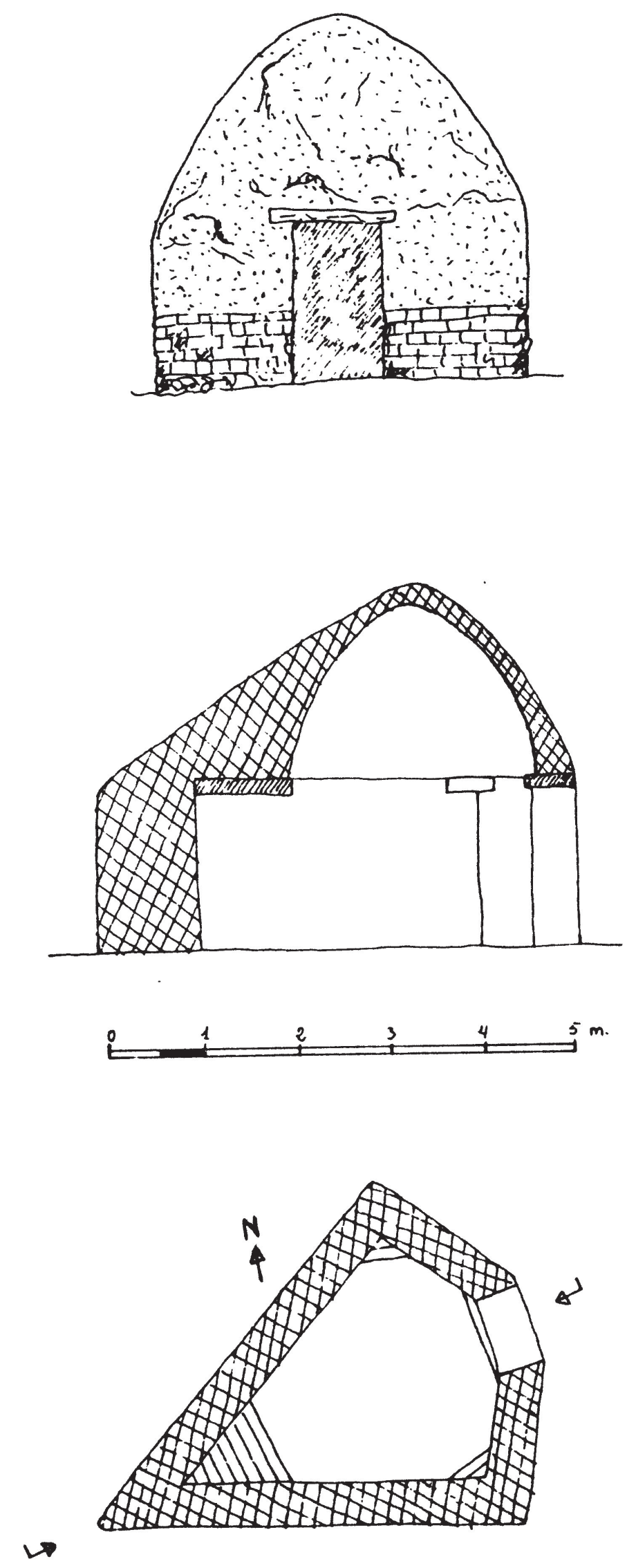

Fig. 24.-Caseta de Villafáfila, de planta poligonal irregular. 

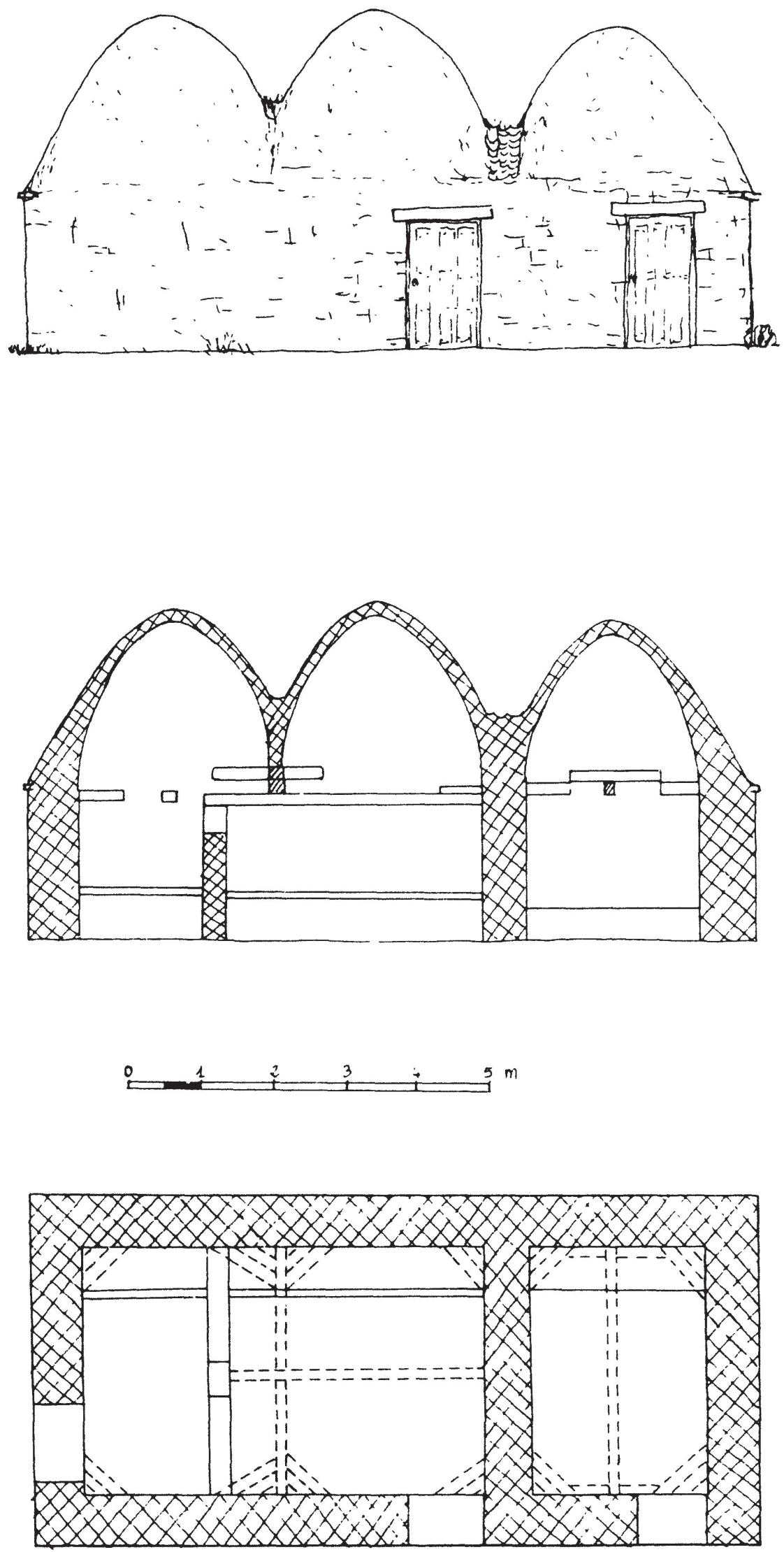

Fig. 25.-Caseta de las eras de Tamariz de Campos (Valladolid), de planta rectangular que se cubre con tres cúpulas apuntadas. 

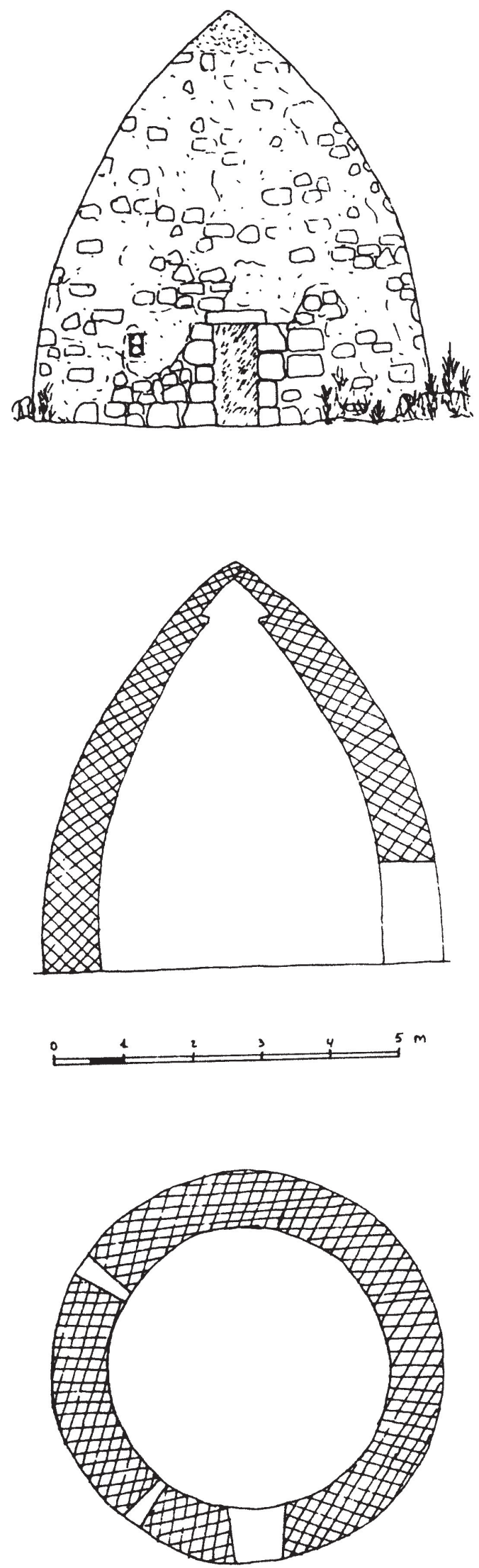

FIG. 26.-Caseta de San Cebrián de Mazote (Valladolid), de planta circular y grandes dimensiones. 


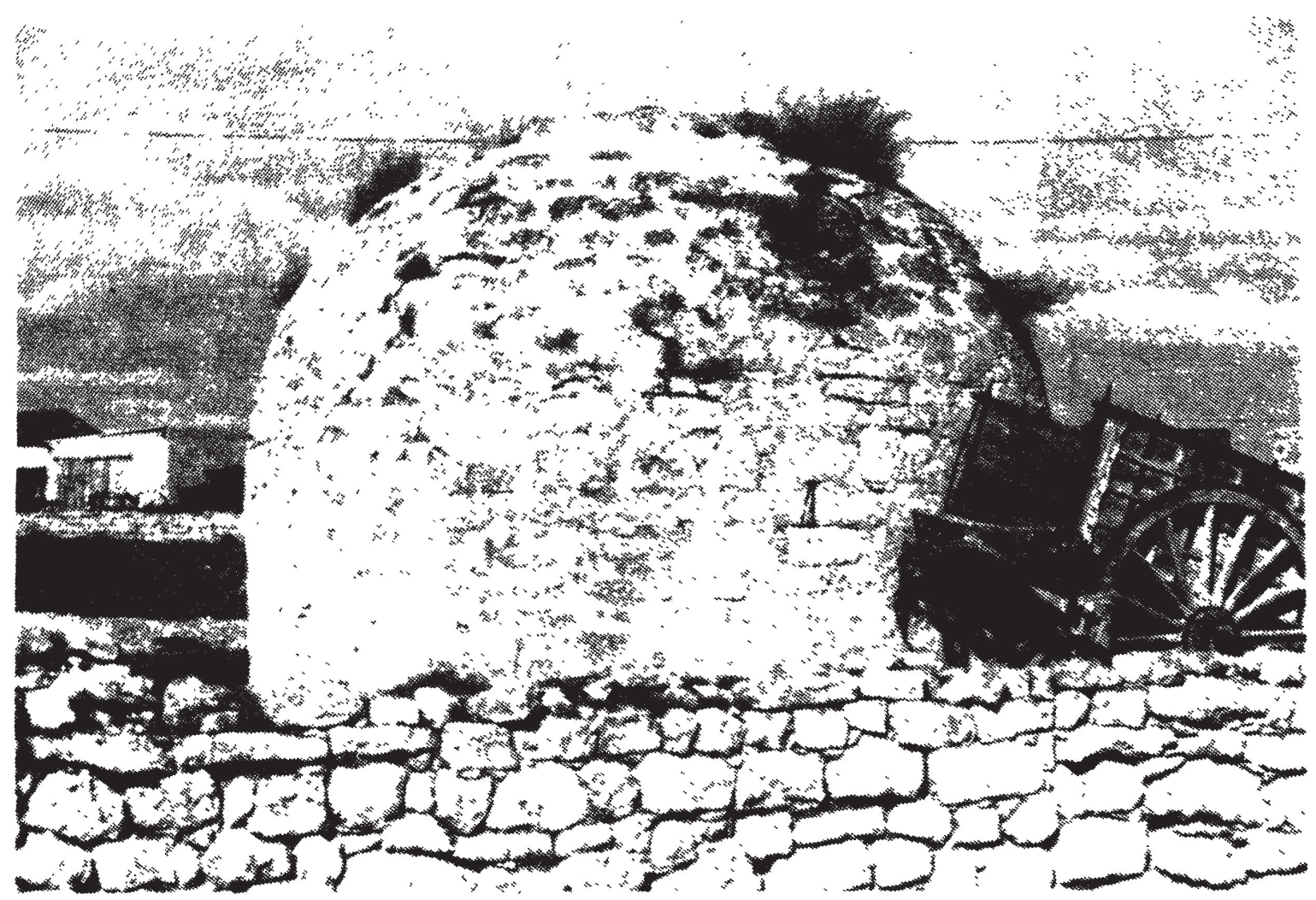

LÁm. IV.a.-Caseta de piedra de planta redonda, con cúpula semiesférica cuya clave es una muela de molino, Montealegre.


LÀM. IV.b.-Casetas en las eras de Urueña, aquí llamadas chozos. 

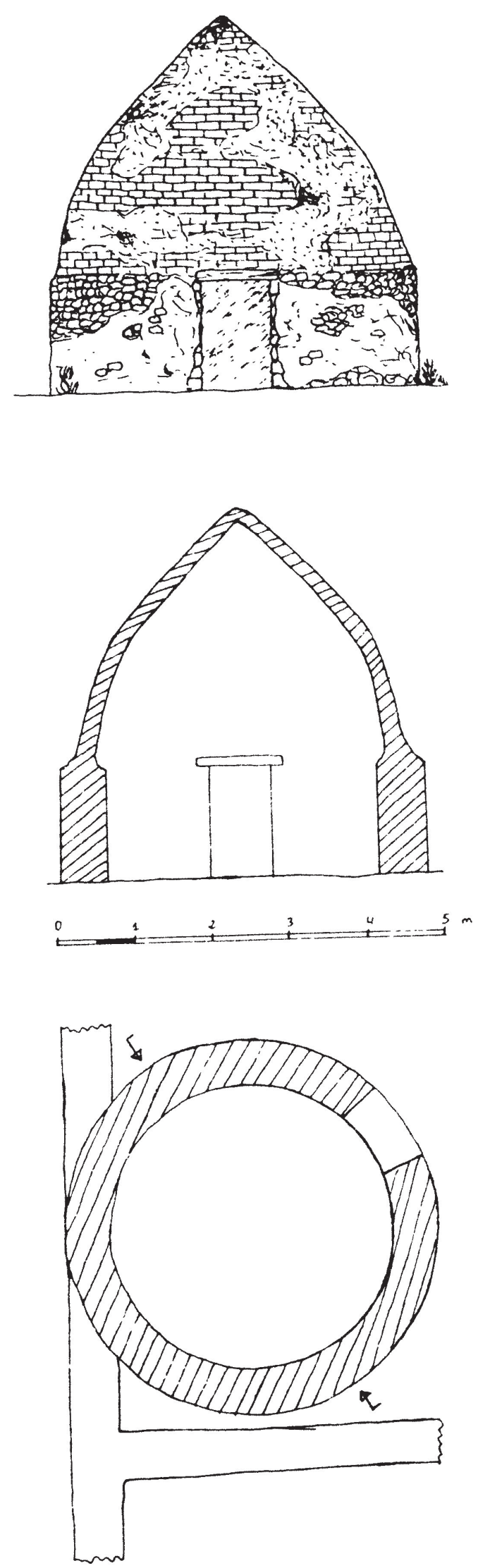

FIG. 27.-Caseta de Urueña (Valladolid), de planta circular, construida con piedra y adobe. 

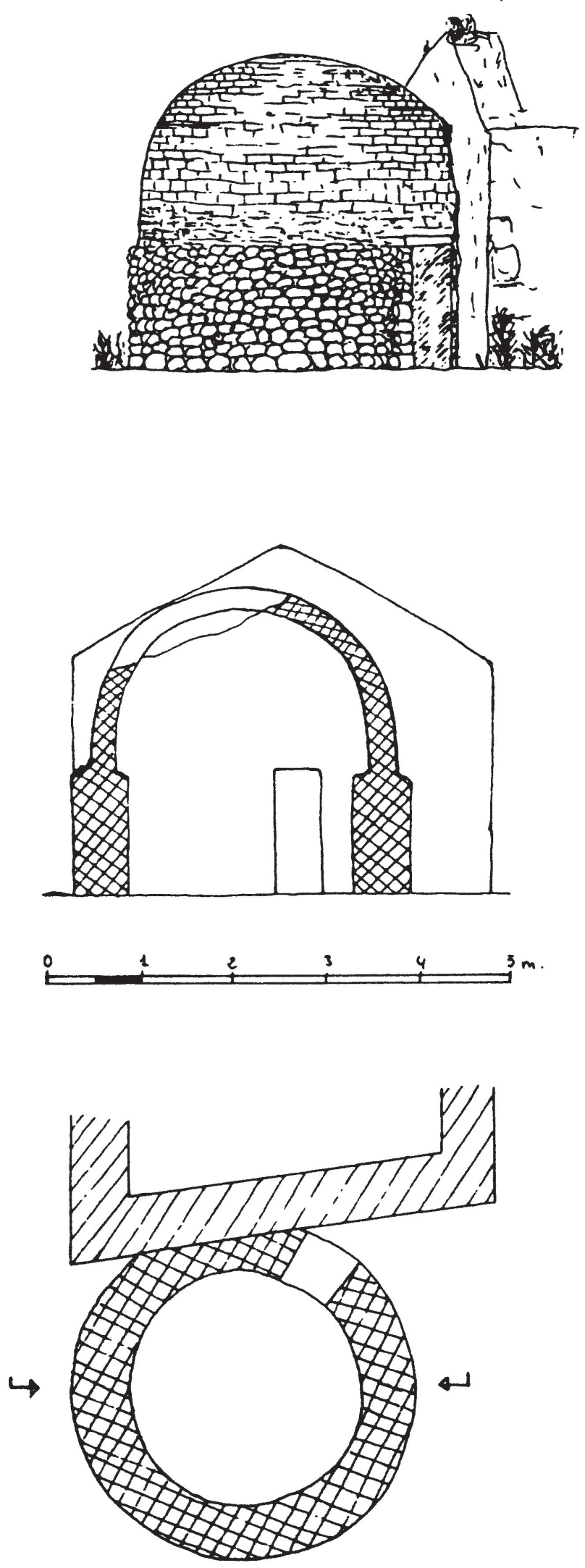

Fig. 28.-Caseta de Urueña, parecida a la precedente pero ésta tiene la cúpula semiesférica. 

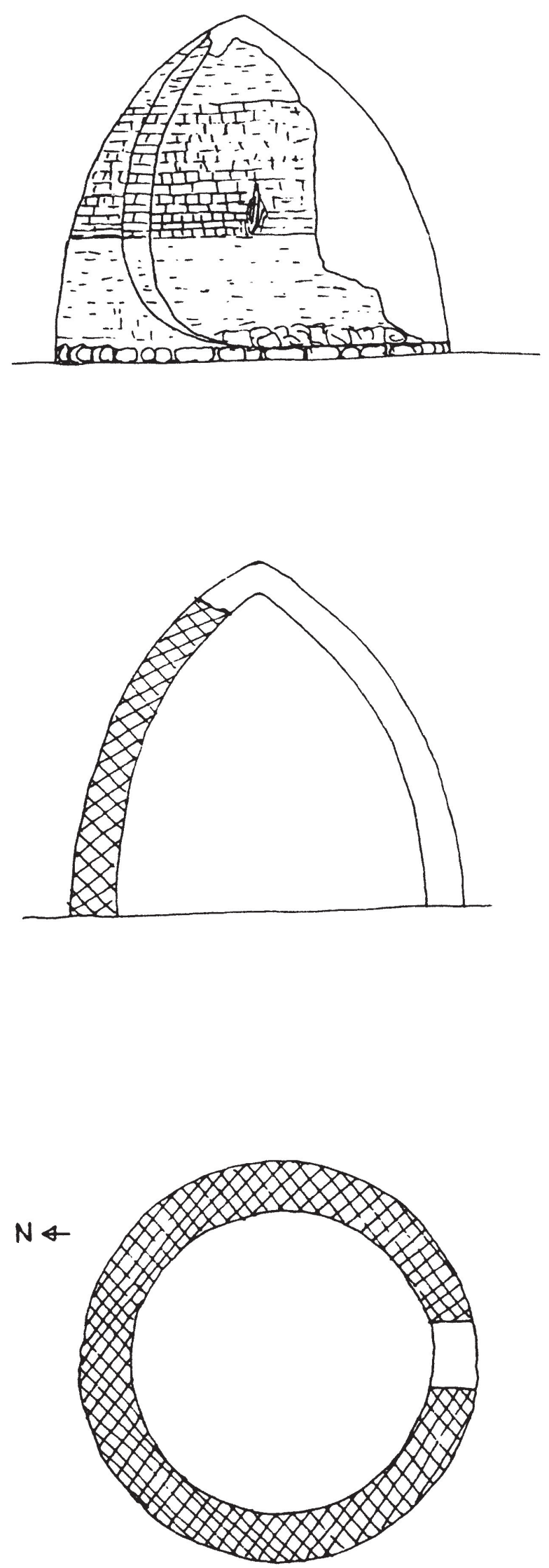

Fig. 29.-Caseta en las eras de Torrelobatón (Valladolid), muy arruinada. 

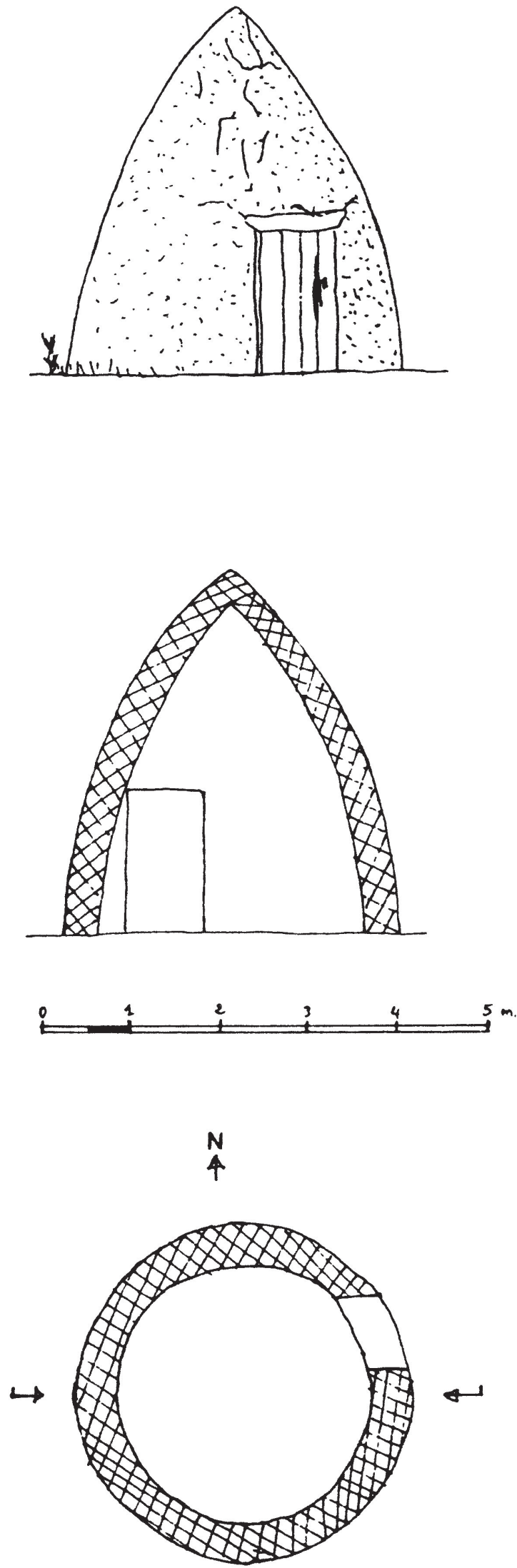

FIG. 30.-Caseta de Torrecilla de la Abadesa (Valladolid), de planta redonda. 


\section{Cabañas}

Son refugios construidos en pleno campo para resguardo ocasional de los labradores. Antes eran especialmente abundantes en los viñedos pues los campesinos pasaban muchas horas en ellos por hacerse todas las labores a mano ${ }^{18}$. Aquí sólo nos fijaremos en aquellas que están cubiertas con cúpula de aproximación de hiladas.

Una forma frecuente es la del chozo, imitación del pastoril, pero levantado en tierras de labor, generalmente antiguas viñas, con muros más estrechos y algunos ventanucos (fig. 31). También podemos hallar cabañas semejantes a las casetas de era de planta cuadrada, aunque algo menores; las hay de piedra (fig. 32) y de adobe (fig. 33), con hogar y chimenea para poder hacer fuego cómodamente. Esto es relativamente normal en las cabañas, y no en los chozos pastoriles (lám. V.a).

De planta rectangular es el ejemplo de Montemayor de Pililla (fig. 34), con hogar al fondo y cubierta de losas de considerable tamaño colocadas por aproximación de hiladas. De planta parecida es la de Valoria del Alcor (fig. 35) que tiene un extraño recinto en uno de sus lados, relleno por las piedras que sacan los labradores al labrar el páramo. Está cubierta con una bóveda apuntada hecha de mampuestos pequeños e irregulares.

\section{Pozos}

Por estar nuestra región dentro de la España seca, ha sido siempre tierra de muchos pozos. Unos apenas son otra cosa que un agujero en el suelo; otros están protegidos por un hermoso brocal de piedra y suelen tener una pila para abrevadero de los animales. Cuando se hacían en las eras, solían situarse dentro de las casetas, como hemos visto en algún caso, o adosados a ellas. También los hay separados y con su propia construcción protectora cubierta con falsa cúpula. Pueden ser de adobe, tanto de planta circular como cuadrangular (fig. 36), o de piedra, como el de Villalba de los Alcores que presenta planta de herradura y cupulilla casi semiesférica rematada por un cono de piedra (fig. 37).

18 Ver al respecto mi artículo, «La cultura tradicional de la viña en la Ribera del Duero (Burgos)», RDTP, XLIV (1989), pP. 227-252. 

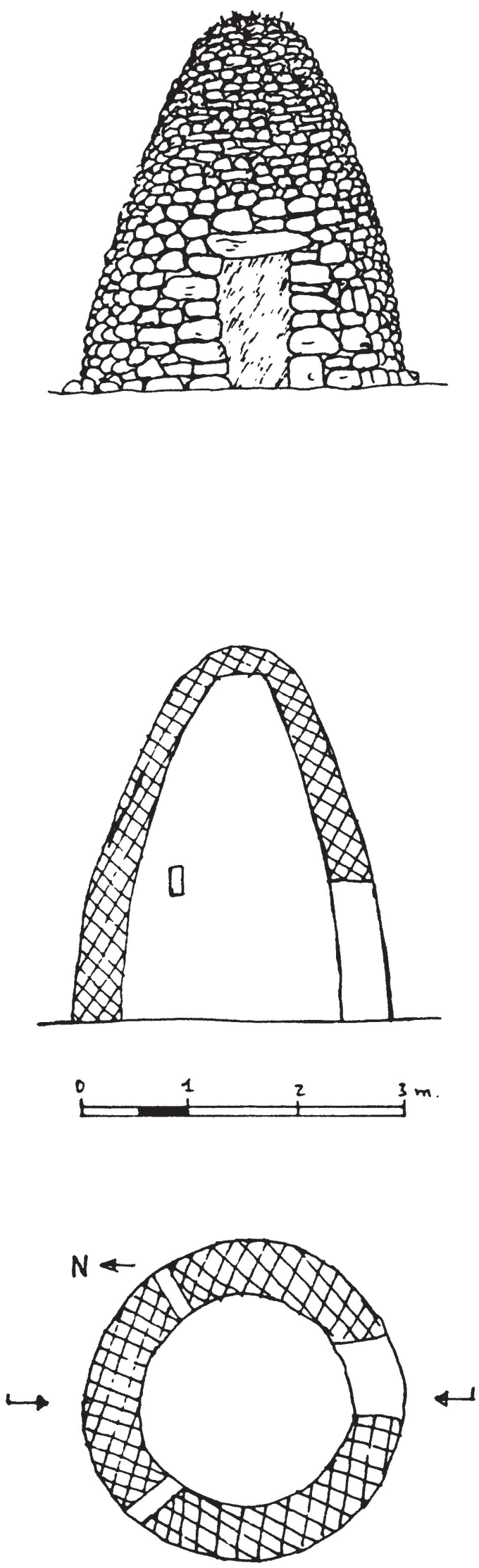

FIG. 31.-Cabaña en forma de chozo en una viña de Castrillo de la Vega (Burgos). 

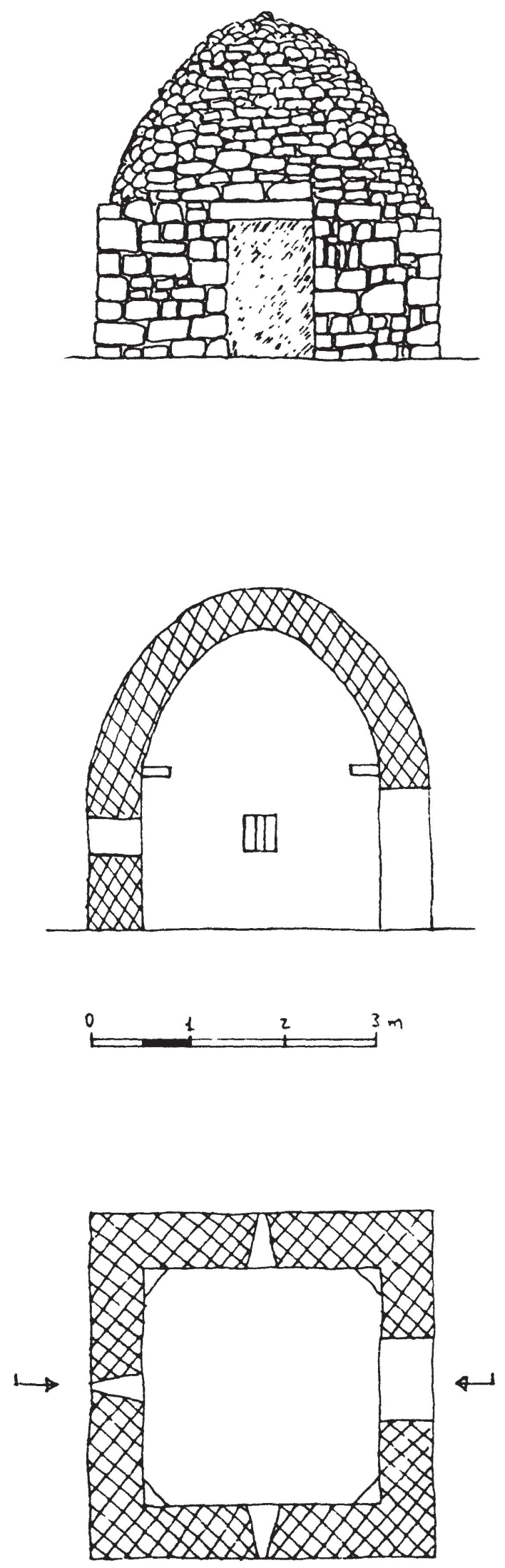

FIG. 32.-Cabaña del Carrascalejo (Valladolid), semejante a una caseta pero con ventanucos. 

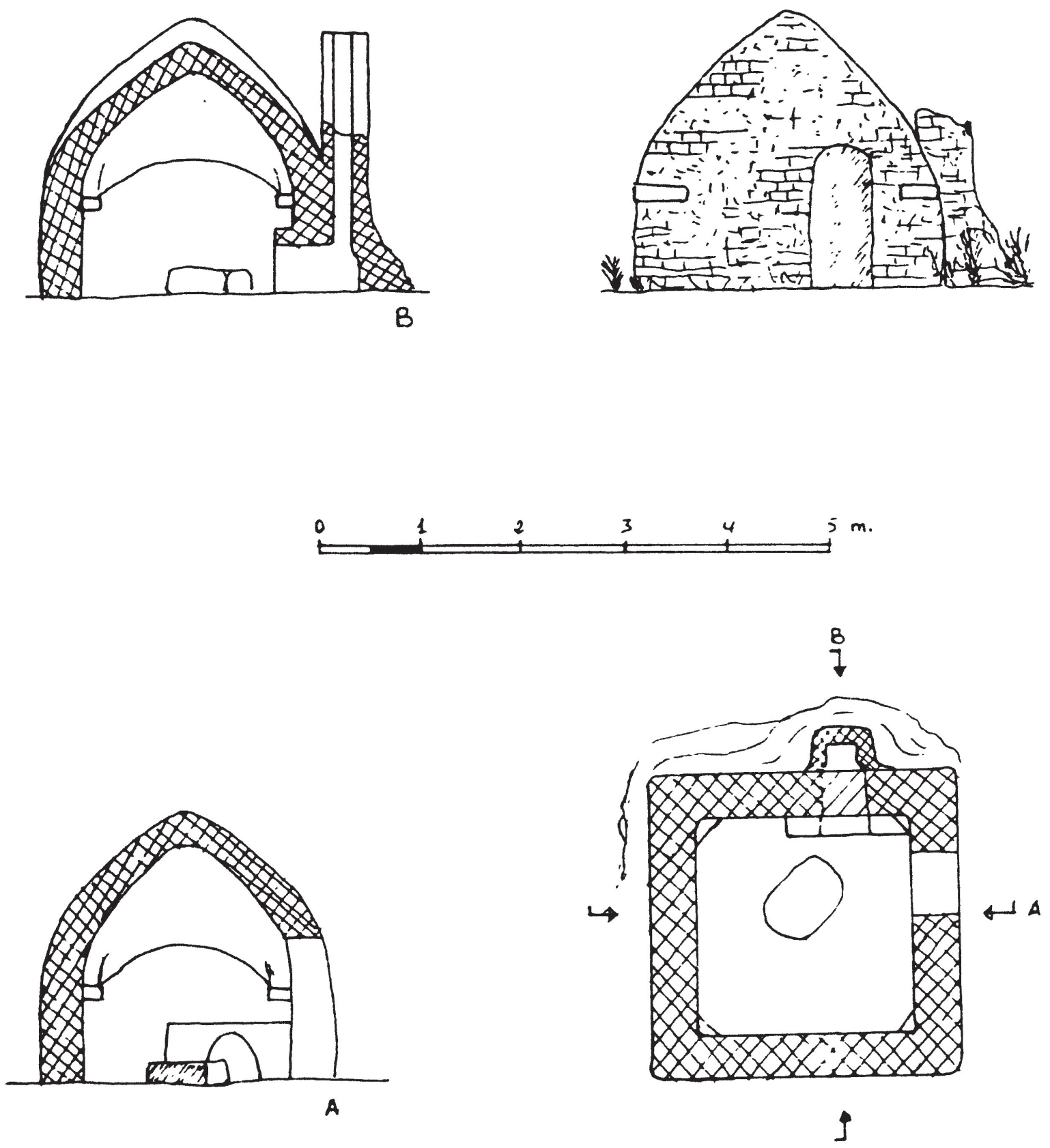

Fig. 33.-Cabaña de adobe, con hogar y chimenea, en Valdenebro de los Valles (Valladolid). 


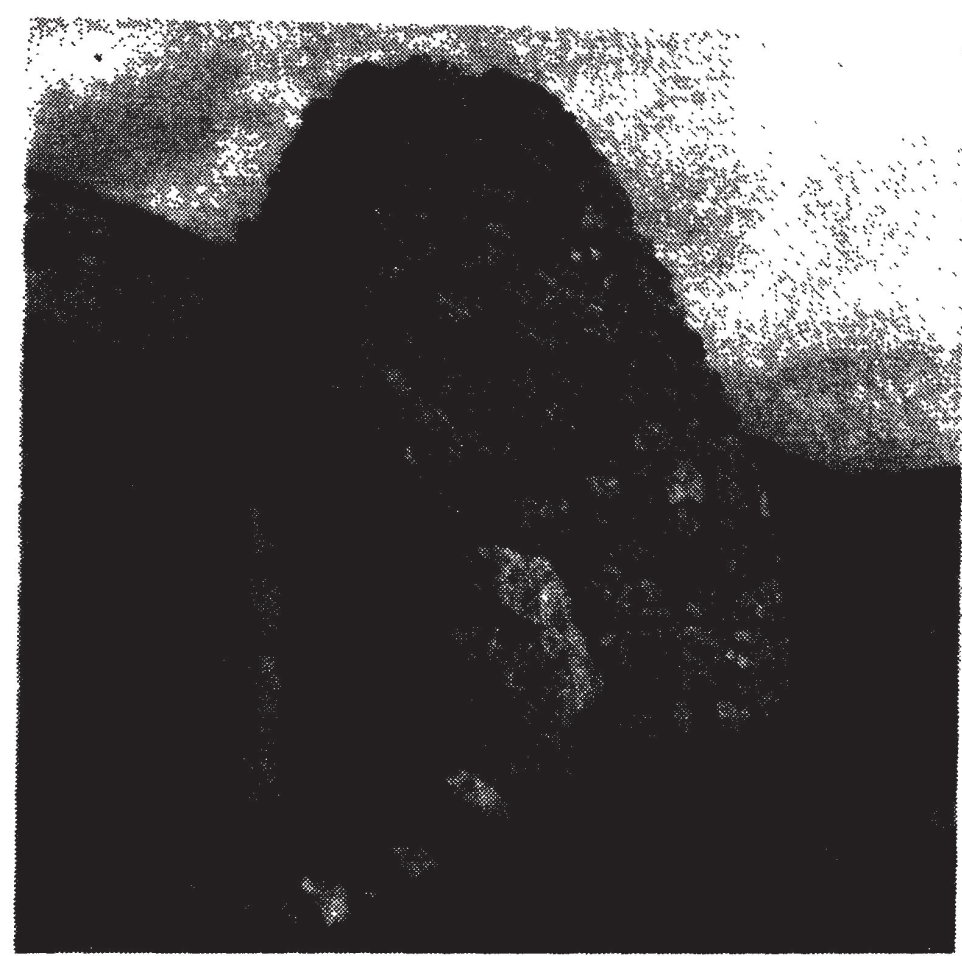

LÁM. V.a.-Cabaña semejante a los chozos de pastores, Milagros (Burgos).

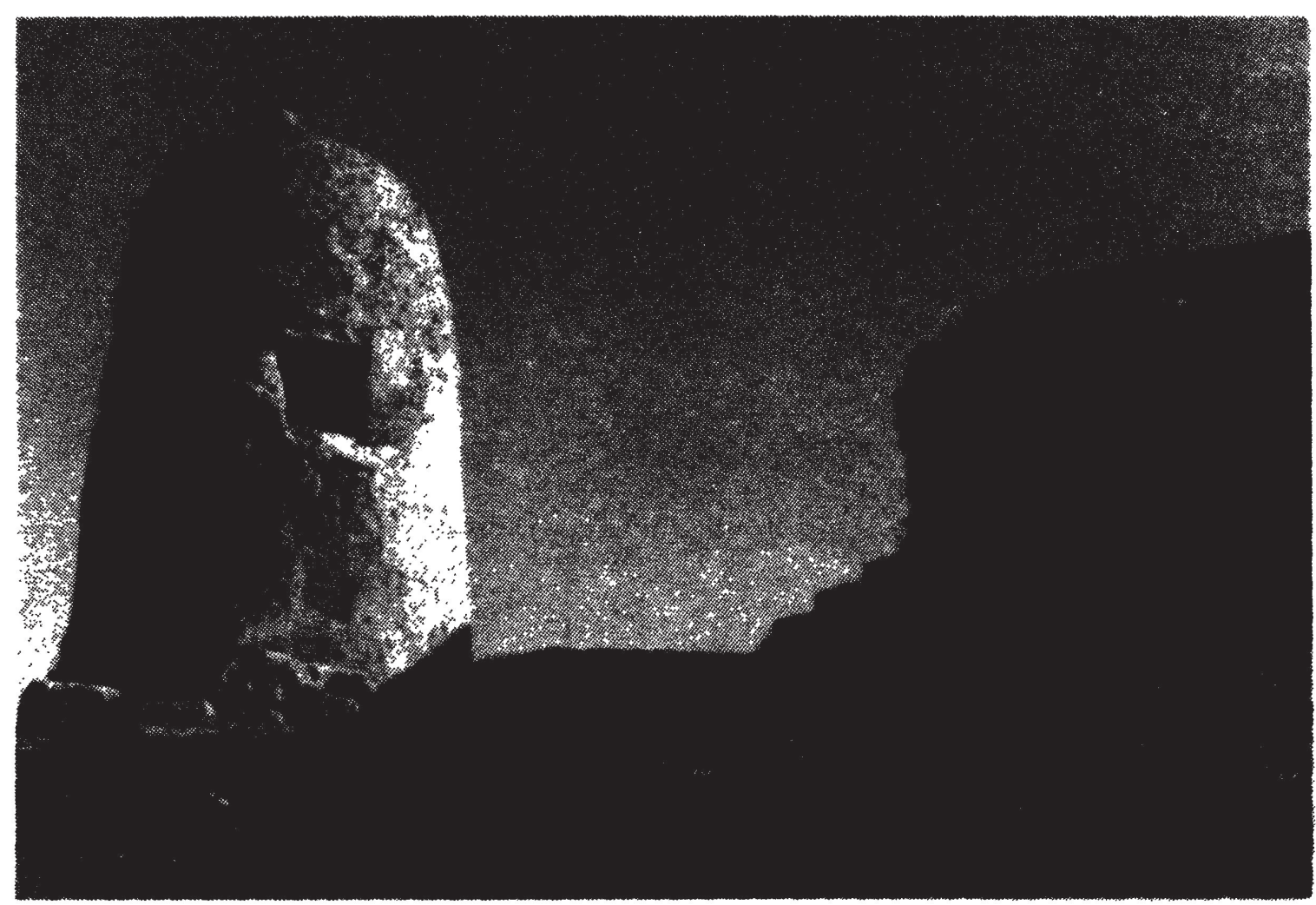

LÁM. V.b.-Zarcera de Castrillo de la Vega (Burgos). 

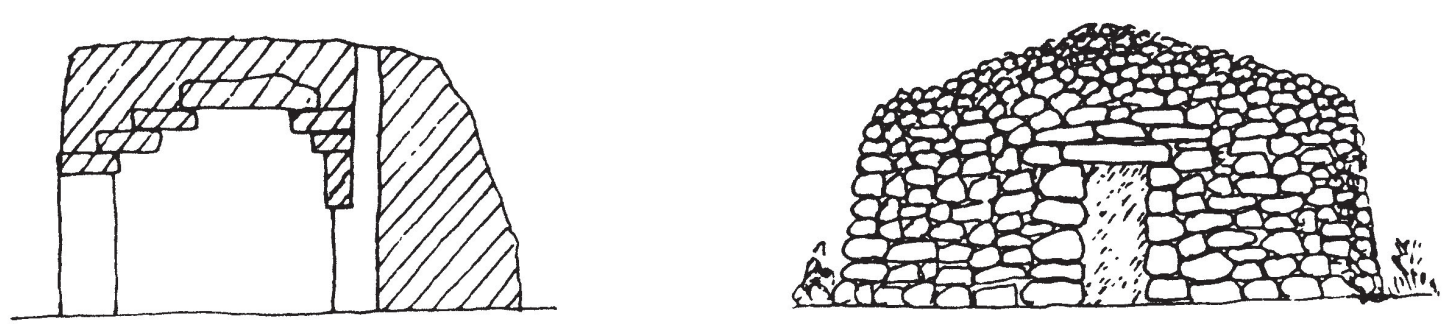

B

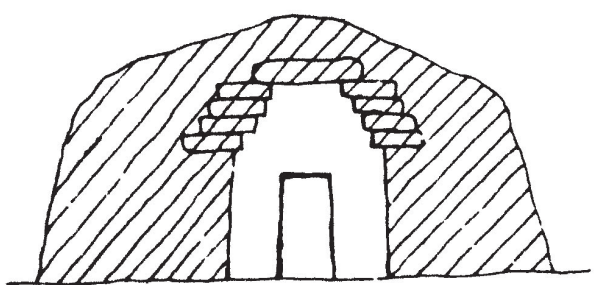

A

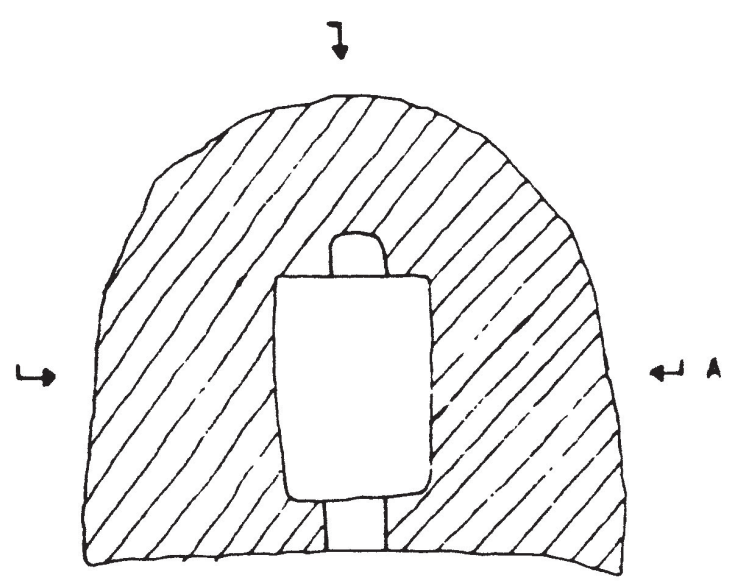

$\frac{1}{B}$

Fig. 34. - Cabaña de piedra en Montemayor de Pililla (Valladolid). 

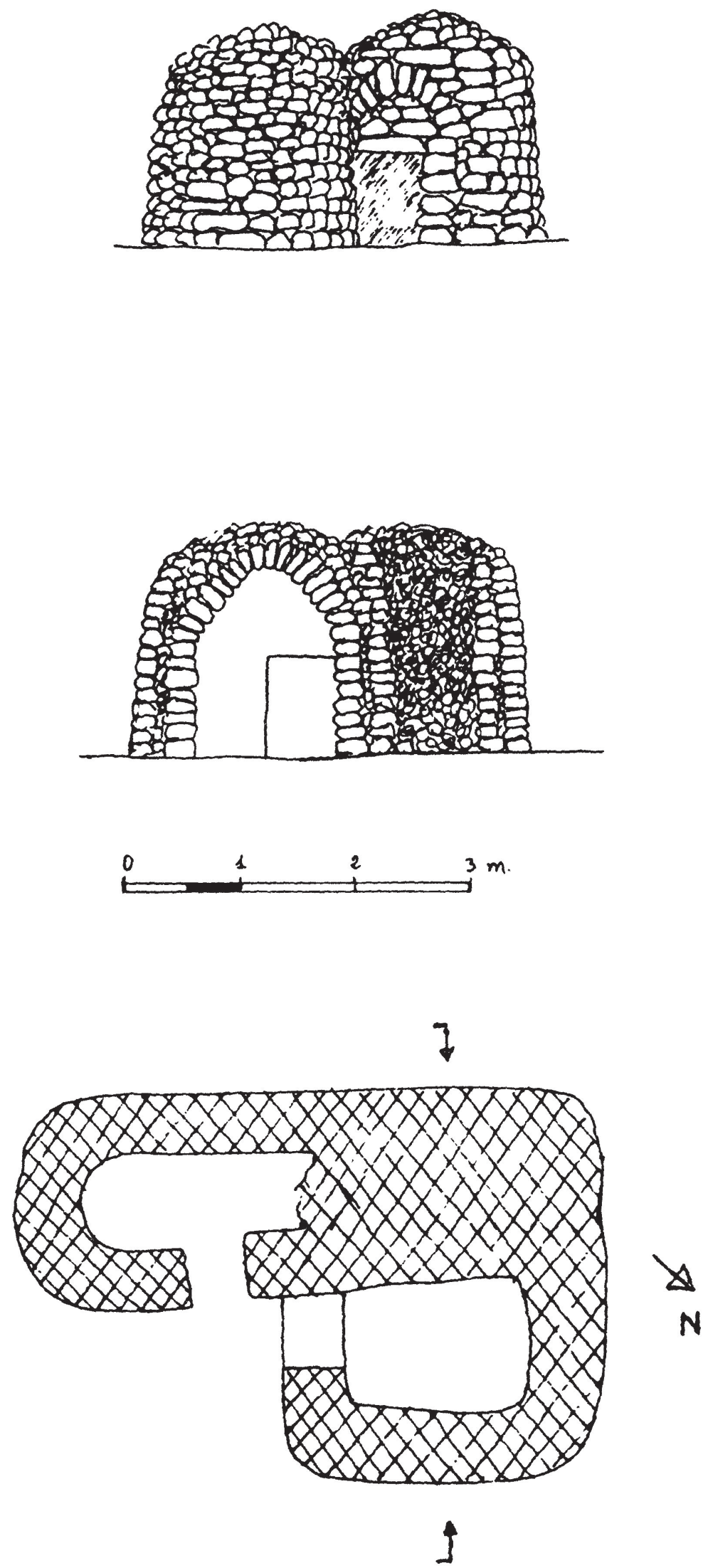

Fig. 35.-Cabaña de piedra, con bóveda apuntada, en Valoria del Alcor (Palencia). 

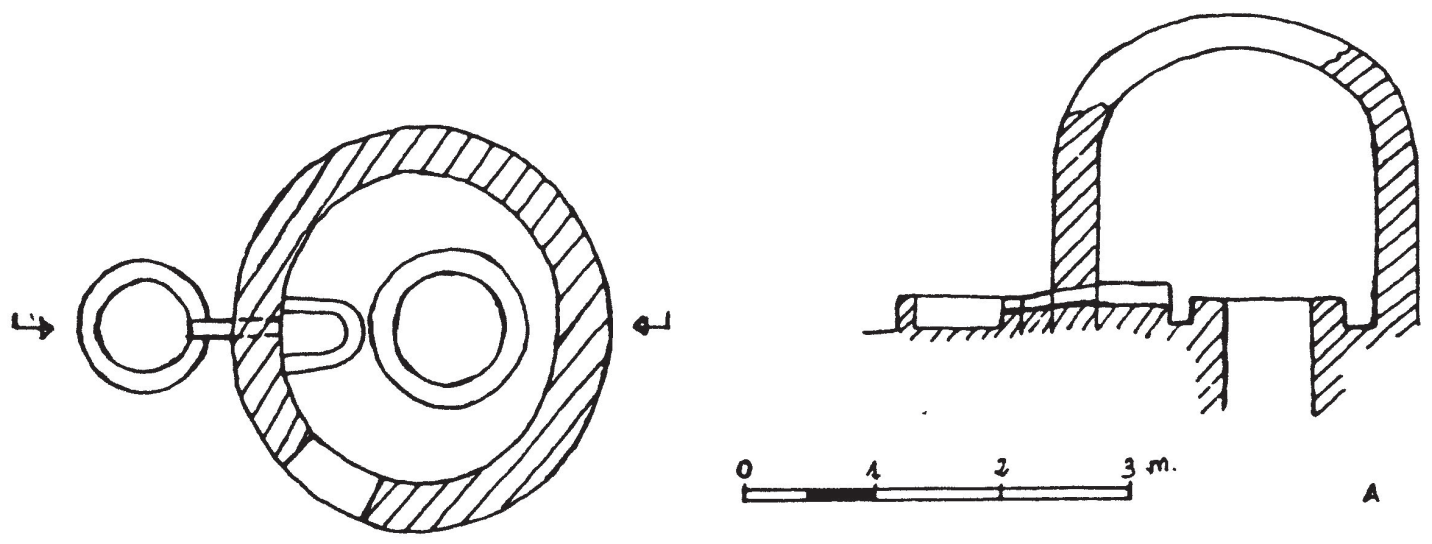

A
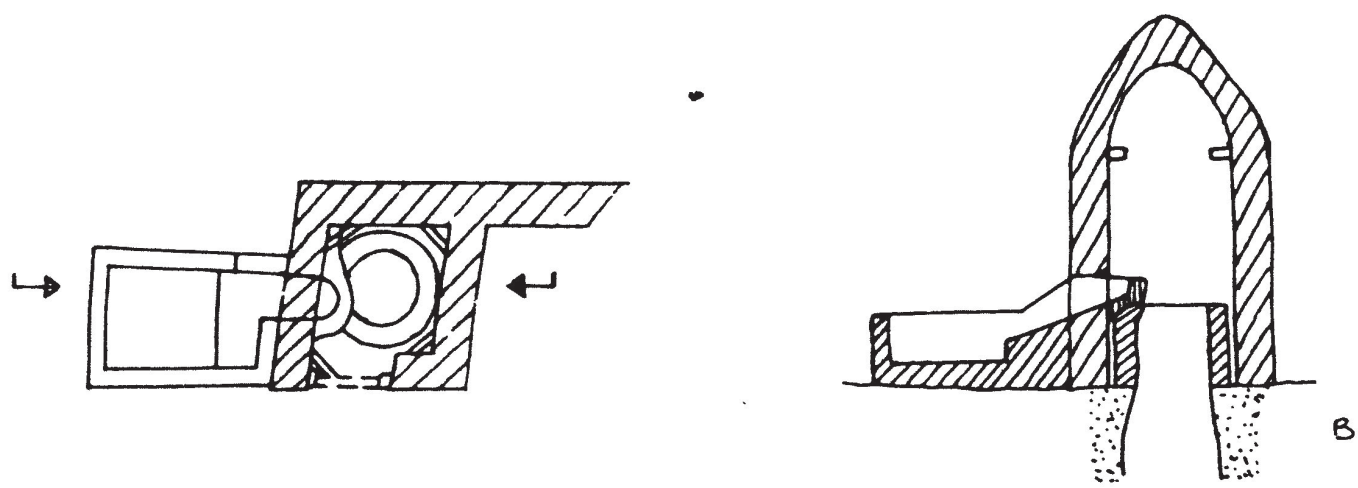

FIG. 36. - a) Pozo en las eras de Becerro (Valladolid). b) Pozo en las eras de Palacios de Campos, de la misma provincia. 

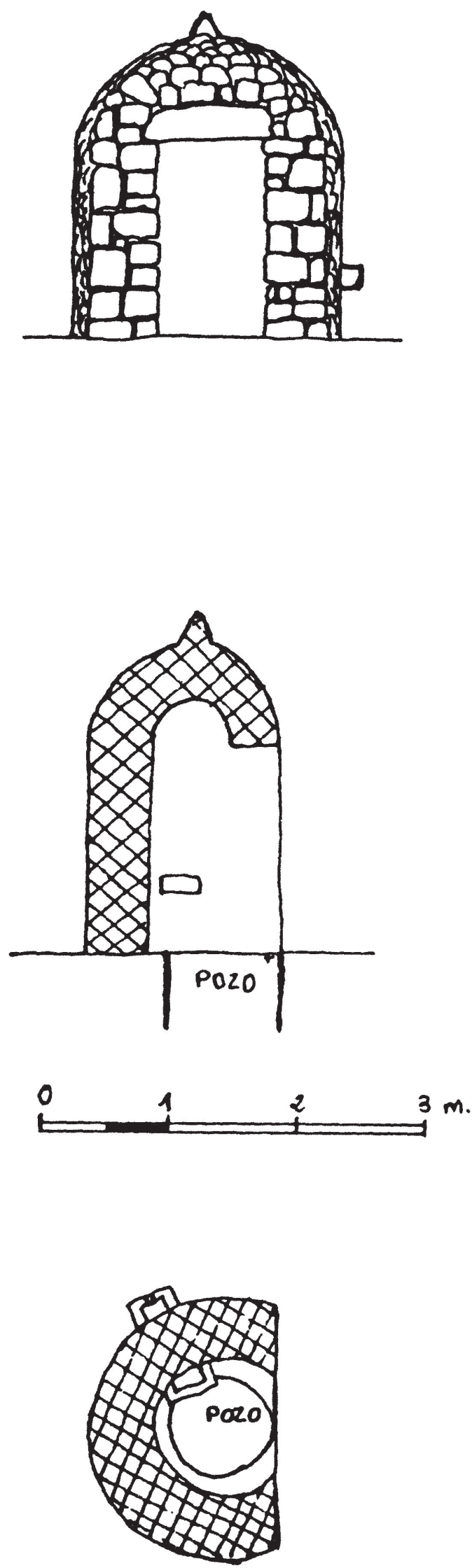

FIG. 37. - Pozo en las eras de Villalba de los Alcores (Valladolid), de planta de herradura. 
El pozo del Rebollar es un manantial con abrevadero para ganado, que se protegió con una especie de chozo de piedra, de planta circular (fig. 38).

\section{Zarceras}

La zarcera o cercera es un pozo de aireación que comunica el fondo de la bodega con el exterior, recubierto con una estructura construida para evitar que personas o animales puedan caer en él. Esta estructura suele ser de planta circular y sección elipsoidal, parecida a los chozos pero en pequeño, pues su diámetro interior no supera generalmente el metro y no suele tener más de dos metros y medio de altura (lám. V.b). Este tipo de zarcera se da en dos de las zonas vinícolas del país; construida en piedra la vemos en la Ribera del Duero (fig. 39) y otras zonas de Burgos, Palencia, Valladolid, Soria y Segovia, mientras que en adobe se construyeron en Tierra de Campos y áreas circundantes.

En los lagares subterráneos hay unas zarceras parecidas a las de las bodegas, pero con una puerta por la que se descargaba la uva que caía por la zarcera a la pila. Menos frecuentes son las de planta cuadrada, como la de Ampudia que se cubre con una especie de bóveda de aristas (lám. VI.a y b).

\section{CONCLUSIONES}

- La técnica de la falsa cúpula, de orígenes remotos, se ha mantenido en uso en construcciones secundarias rurales, como chozos de pastores, casetas de era, cabañas, pozos y zarceras de bodega, hasta nuestros días.

- Son construcciones pequeñas edificadas generalmente por los propios usuarios con los materiales del terreno. Su carácter utilitario no les impide integrarse con armonía en el paisaje; al contrario, forman parte de él.

- Algunos de estos edificios, como los chozos, tienen rasgos arcaicos y parecidos sorprendentes con ciertas construcciones prehistóricas, que nos hablan de una tradición técnica milenaria.

- Otras edificaciones, como las casetas de era, tienen mayor complejidad técnica, el paso de la planta cuadrada a la circular se ha solucionado de diferentes maneras, quizá con la ayuda de la arquitectura culta, como podría indicarnos el uso de pechinas.

- Carecen de elementos decorativos, si descontamos los remates superiores, que par sus constructores tenían una función protectora y no decorativa. De todas formas, la elementalidad de sus formas desprende una belleza realzada por el medio físico en que se hallan. 

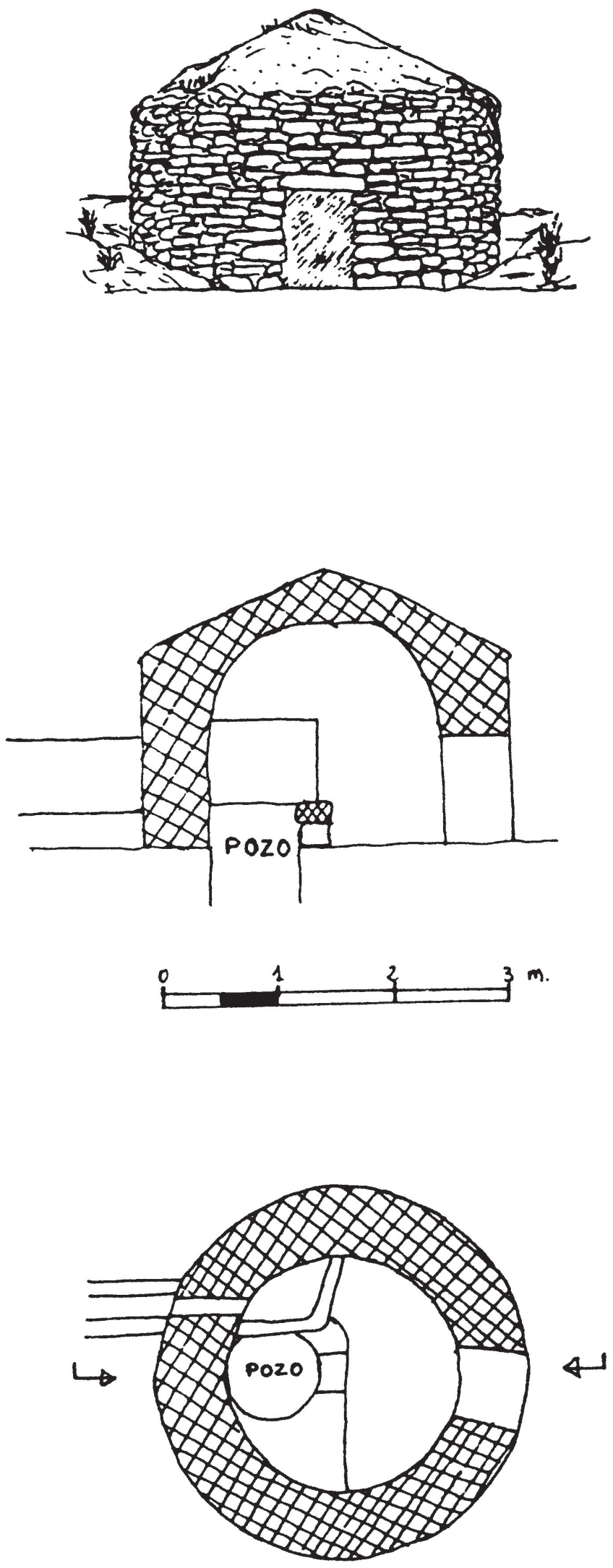

FIG. 38.-Pozo del Rebollar (Valladolid), parecido a un chozo. 

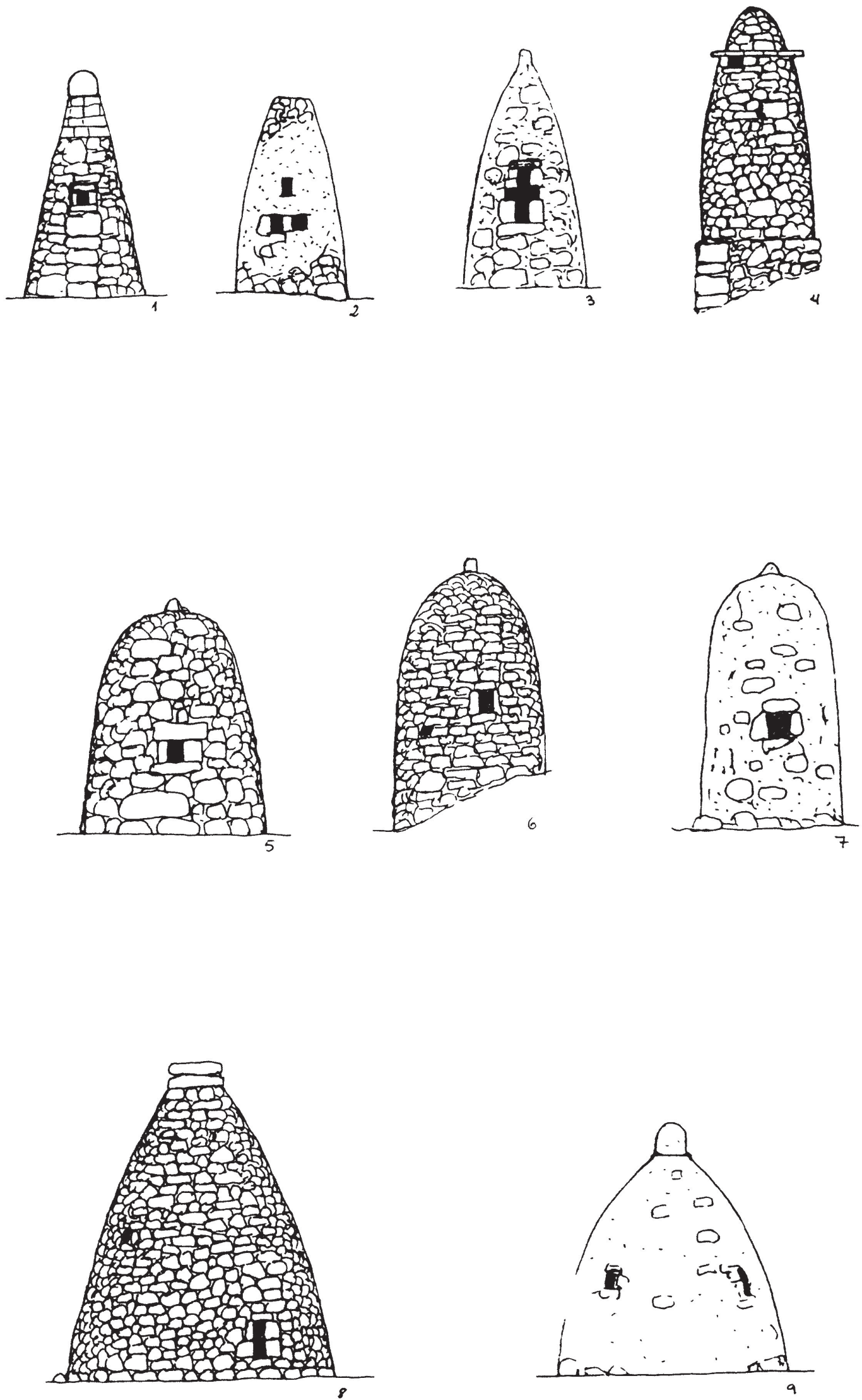

Fig. 39.-Zarceras de piedra de la Ribera del Duero (Burgos). 1 y 3, de La Horra; 2, 5 y 7 de Castrillo de la Vega; 4 y 6 de Torregalindo; 8 de Baños y 9 de San Martín de Rubiales. 


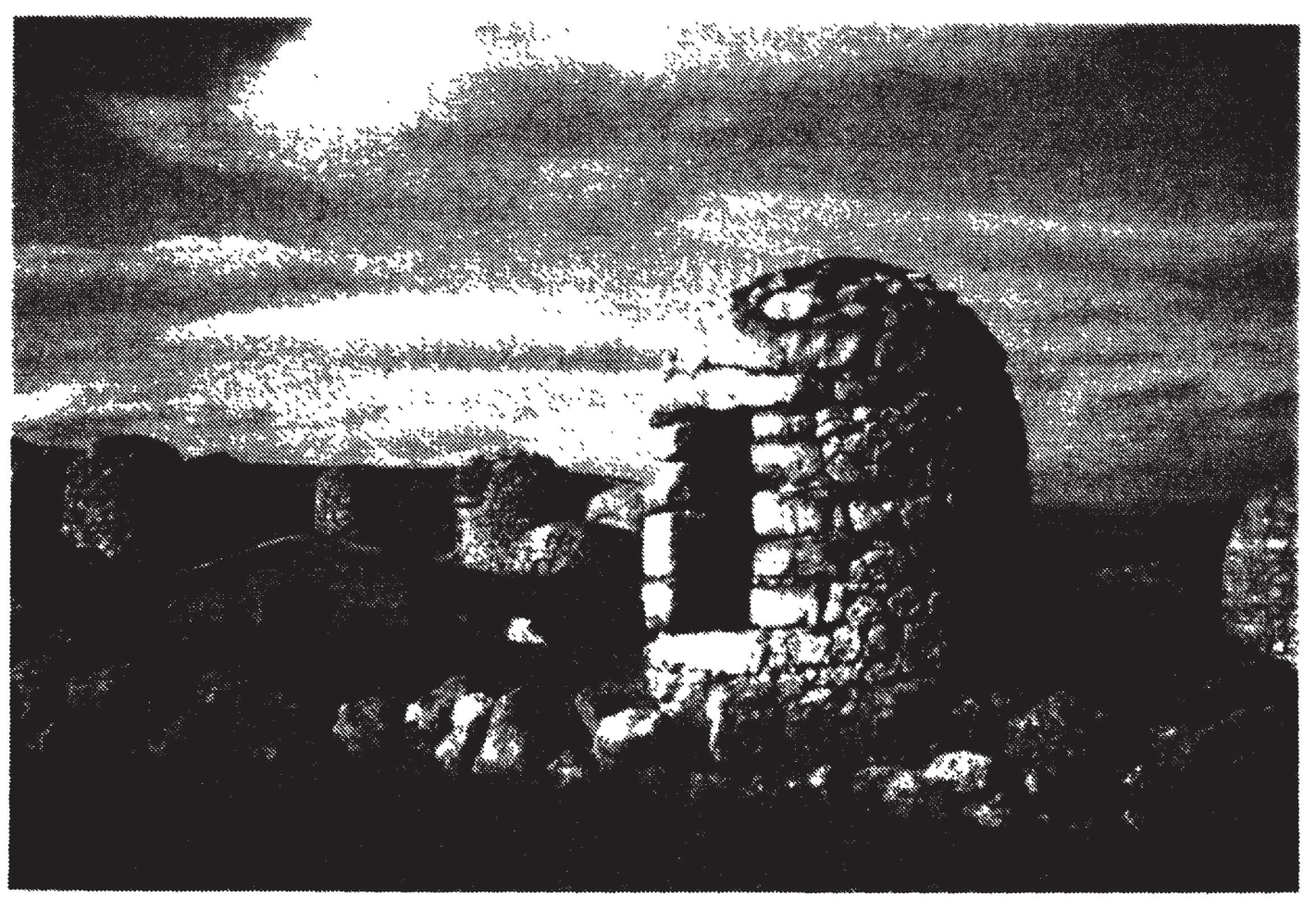

LÁM. VI.a.-Zarcera, o lucera, de lagar, Valoria del Alcor (Palencia).

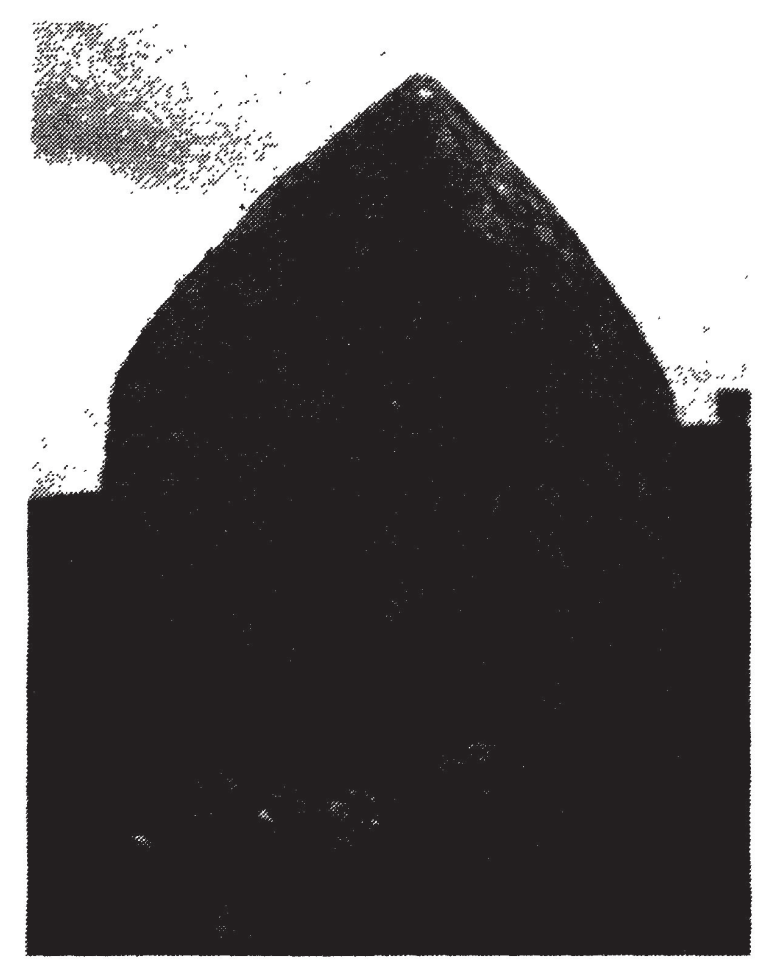

LÁM. VI.b. - Zarcera cuadrada de una bodega de Ampudia (Palencia). 
- Su estado de conservación es malo, especialmente en el caso de las casetas de adobe y tapial porque les faltan desde hace años los cuidados de conservación necesarios. Su ruina progresiva e inevitable nos priva de una parte de nuestra arquitectura más atractiva y significativa, además empobrece el paisaje, que es obra de la naturaleza pero también de la acción humana ${ }^{19}$.

\section{ARTURO MARTÍN CRIADO}

Se muestran diferentes clases de construcciones rurales, tanto de planta redonda como de planta cuadrada, que se cubren con cúpulas de aproximación de hiladas, y se constatan algunas relaciones con tradiciones arquitectónicas muy antiguas.

Different types of country buildings are mentioned this article, which have either a round foundation or a square foundation, and are both covered by a false dome; some of their characteristics are found to be somehow related to some of the oldest architectural traditions recorded.

19) En la mayoría de las obras que tratan el tema de la arquitectura popular se dedica algún apartado a los refugios y edificaciones secundarias, sin profundizar demasiado en su estudio. A continuación ofrecemos una bibliografía específica: J. de AGUIRRE, «Chozas y cabañas. Techumbres», Anuario de Eusko-Folklore, V, 1926, pp. 125-129; J. M. de Barandiarán, "Contribución al estudio de los refugios del País Vasco», Anuario de EuskoFolklore, VII (1928), pp. 41-47; B. BAS LÓPEZ, Los chozos: una arquitectura peculiar del suido (La Coruña, 1986); C. Carricajo Carbajo, Arquitectura popular: construcciones secundarias (Temas didácticos de cultura tradicional núm. 20) (Valladolid, 1990); E. CASTELlote HERRERO, «Arquitectura y trabajo: construcciones auxiliares agrícolas y ganaderas en La Alcarria», en Arquitectura Popular en España (Madrid: CSIC, 1990), pp. 551-558; J. L. CONSTANTE LlUCH, "Refugios en el Bajo Maestrazgo: barraques y barraquetes», en Penyagolosa, 15 (1980); M. A. GARCía Alonso, «La cabaña montañesa en el valle de Soba (Cantabria)", Publicaciones del Instituto de Etnología y Folklore Hoyos Sáinz XI (1981-83); A. GARCfa BELLIDO, «Sobre la extensión actual de la casa redonda en la Península Ibérica», RDTP, XXIII (1967), pp. 41-54; M. T. GARCía BERLANGA, «El bombo. Edificación rural de La Mancha», II Congreso de Etnología y Tradiciones Populares (Zaragoza, 1974), pp. 459466; M. García Lisón y A. Zaragoza CATALÁN, «Arquitectura rural primitiva en secá», Temes d'etnografia valenciana, I (Valencia, 1983), pp. 289-338; J. M. GómEZ TABANERA, «El bombo manchego y sus relaciones mediterráneas», II Jornadas de Etnología de Castilla-La Mancha (Guadalajara, 1985), pp. 85-91; M. I. JIMÉNEZ ARQUÉS, «Construcciones populares en los Montes Torozos», Narria, 21 (1981), pp. 7-9; J. C. Labeaga Mendiola, «Los chozos de piedra con cúpula en Viana (Navarra)», Cuadernos de Etnología y Etnografía de Navarra, 33 (1979), pp. 515-535; A. LASTRA VILLA, «Chozos circulares pastoriles en Cantabria», PIEFHS, II (1970), Pp. 149-160; G. LópEZ DE GUEREÑU, «Refugios de La Rioja», Obitura, 1 (1982); Ibid., "Chozas de Campos», Obitura, 2 (1984), 3 (1985) y 4 (1986); L. C. Navarro, "Arquitectura popular en Tomelloso: los bombos», II Jornadas de Etnología de Castilla-La Mancha (Guadalajara, 1985), pp. 271-286; J. RuBIo BELLVER, «Construccions de pedra en sec», Anuario de la Asociación de Arquitectos de Catalunya (1914); A. RuIZ AgüEro, «Chozos circulares», Narria, 12 (1975); M.* E. SÁNCHEZ SANZ y M.“ P. TIMÓN Tiemblo, «Aportación al estudio del chozo en la provincia de Cáceres», Narria, 23-24 (1981), pp. 3-6; B. TARAcena AgUiRre, «Una cabaña circular en Vinuesa (Soria)», Archivo Español de Arte, 43 (1941); R. Violant I SimORRA; "Las "barraques" de viña, de pared en seco, de Pla de Bages (Barcelona)», Estudios Geográficos, 55 (1954), pp. 189-200. 